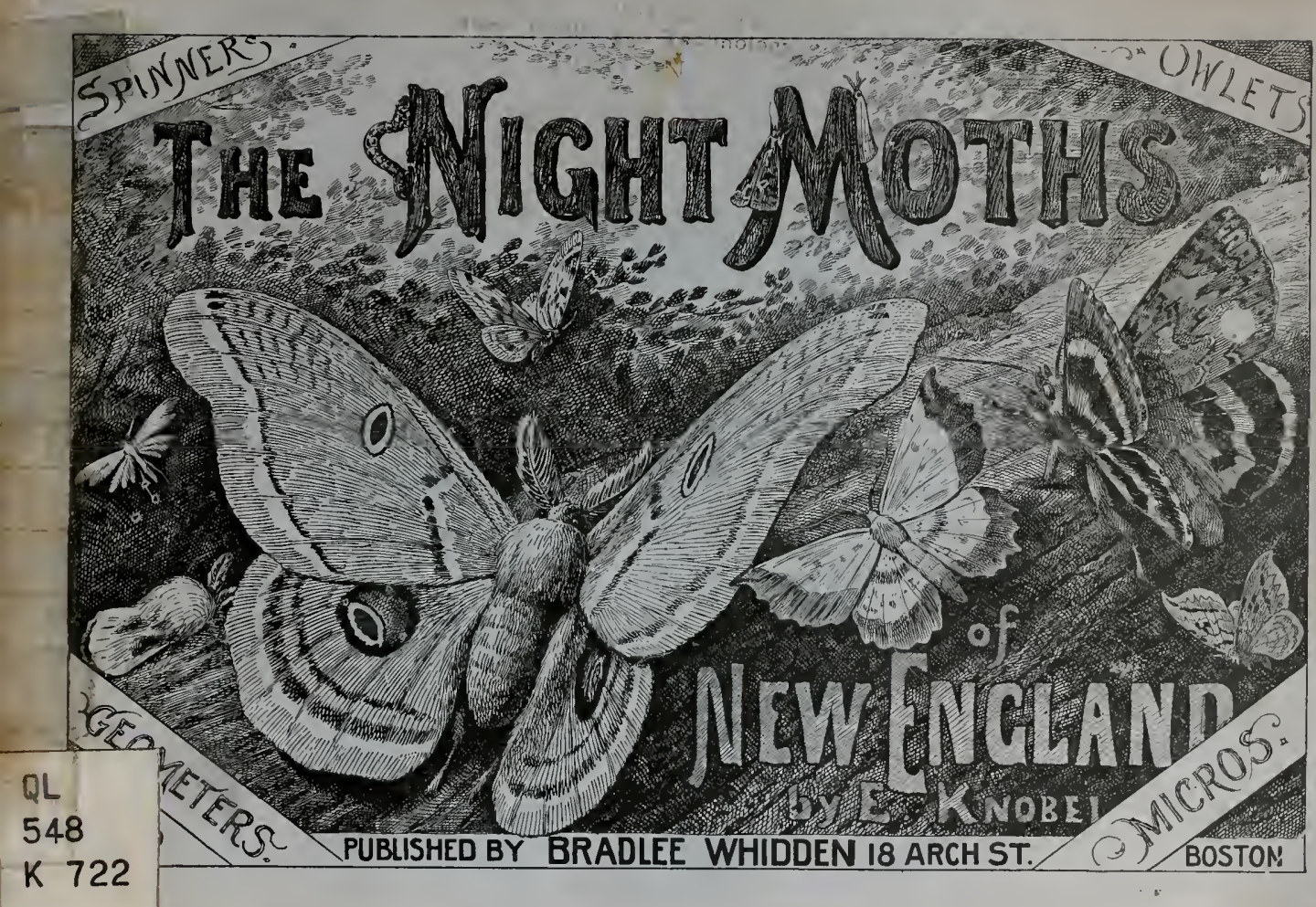




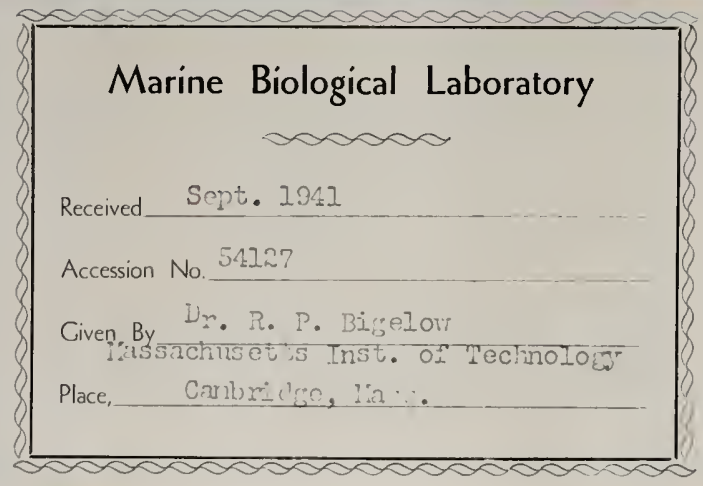




\title{
OF NEW ENGLAND
}

HOW TO DETERMINE THRE RERALY

\author{
BY EDWARD KNOBEL.
}




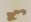

\section{Copyright, 1895,}

by

E. KNOBEL. 


\section{NOCTURNAL LEPIDOPTERA.}

THE night moths, or millers (nocturnut lepidoptera) are distinguished from all other butterflies by their feelers, which taper from their base to the point and are often feather-like; by their wings which, when at rest, are shut upper-side outward and more or less steep or roof-like over their bodies.

The different families have been arranged in seven groups, of which the first three embrace the larger moths. These three groups lead gradually from one to another with no distinct line of demarcation, so that often a spinner is taken for an owlet, or a geometer for a spinner. Therefore, if a specimen cannot be found in the group that it seems to resemble it will be found in another similar to it. The last groups contain the smaller moths, which are mostly recognized by parts of their heads and veins of their wings, - too minute for consideration in this book. Only a few, therefore, of each family are represented to give an idea of their character. On account of the great number of moths, the majority of which are so nearly alike in coloration and size, as well as the variations in size

and color among themselves, - the females often being double the size of the males, - it is always difficult to determine the name of a motin which has no decided markings. Even their own wear and tear make them often unrecognizable.

Abbreviations used in the descriptions are as follows : f. for forewing, h. for hindwing, c. for food plant of the caterpillar. The word "like" is used, meaning similar in shape and marking, but not in color and size. 
THE MOTHS are divided into the following groups :-

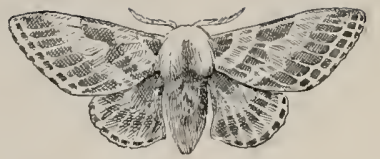

I. Spinners : - Feeler feather-like or comb-like; forewing broad and large; body stout; heads sunk in the woolly chest part, mouth-feelers not visible. Caterpillars spin a cocoon of silky threads around their pupæ . . . . . . . . Bombicidc, Page 8.

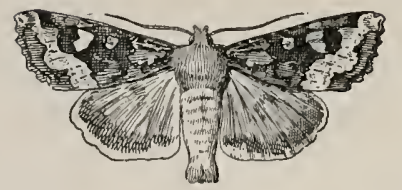

2. OwLETS:- Feeler hair-like and smooth, or sometimes a little comb-like; forewing narrow, generally marked with zigzag cross lines and two peculiar dots or eye marks ; body stout, head and mouth-feeler prominent. Caterpillars form mostly naked pupe or with only a few hairs which they bury in the ground

Noctuce, Page 22.

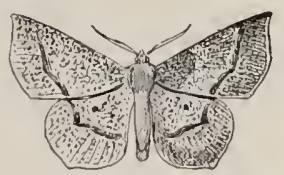

3. Spanners or Loopers:- Feelers of both kinds; wings large, body slender; fore and hind wings mostly alike in color and character. Their caterpillars have only fore and hind legs and therefore span, measure or form a loop in walking . Phalene, Gcometride, Page 47. 

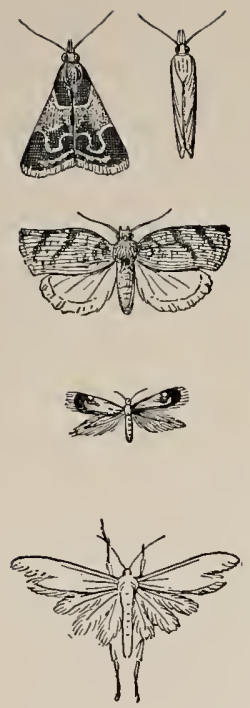

4. Deltoins or Snout Moths:- Feelers hair-like; mouth feelers long, forming a long snout; legs long. They close their wings in shape of a triangle or roll them around their bodies like a cloak

. . . . . . Pyratida, Page 58.

5. LEAF-ROLLERS:- Feelers hair-like; wings round shouldered and oblong; legs short. The caterpillars, when transforning roll the edge of a leaf around their pupe . . . . . Tortricida, Page 60.

6. True Moths:- Small moths with a long, silky fringe around the edge of each wing, the wing itself narrow . . . Tineida, Page 6z.

7. Frather-Motus :- Moths which have their hindwings, and sometimes also their forewings, split to the shoulder, forming three or six feathers.... . . Ptcrophoride, Page 63 . 


\section{Key to Bombicidæ.}

Those which measure with wings spread

One inch or less,

forewing not marked or spotted .

forewing marked or spotted, predominant color

white, cream, or light yellow

rusty, buff or ochre yellow

hindwing plain

hind wing marked or dotted

gray or brown

Between one and two inches :

forewing not marked

forewing white, cream or light yellow

rusty buff or ochre yellow

gray or pale brown :

hindwing gray or brown

buff or rust color .

white or cream color

dark brown, or black with white streaks

Two inches, or more:

forewing or both wings green

white cream, yellow, buff or rusty

gray, or light brown.

dark and light color . 


\section{BOMBICID $A$. Spinners.}

I. Argyrophyes nigrofasciata; $\frac{7}{8}$ in.; cream color, marked brown.

2. Crambidia pallida; $\frac{7}{8}$ in. ; f. buff; h. cream, not marked.

3. Hypoprepia fucosa; 1 in.; f. buff and brown; h. cream with brown, like 4 , only band narrower and paler. c. Lichens. miniata; $1 \frac{1}{8}$ in.; f. buff and brown; $h$.

5. Euphanessa mendica; $1 \frac{1}{8}$ in.; semi-transparent white, not marked.

6. Crocota rubicundaria; I in.; f. buff; h. cream with light brown dot and band.

7. " breqicornis; I in.; cream color and paler, marked like 6 .

8. ". ferruginata; $1 \frac{2}{8}$ in.; cream color and no marks.

9. "quinaria; $1 \frac{1}{8}$ in.; f. rusty buff with two white dots. h. cream and dark brown marks.

c. Dandelion.

10. " immaculata; 1 in. ; yellow buff, not marked.

I1. Utetheisa bella; 11 in.; f. orange and white, black dotted bands; h. pale red with dark brown marks. c. Plum, sweet gale.

12. Callimorpha interrutio marginata; 2 in.; cream color and dark brown.

13. "lecontei; 2 in.; f. white and brown; h. white, not marked.
14. Platarctia parthenos; $2 \frac{1}{2}$ in.; f. light brown with buff spots; h. buff with black marks.

c. Wild lettuce.

1 5. Arctia virgo; 2 in.; f. black with buff streaks; h. red with black spots. c. Goosefoot.

16. " saundersii; $\mathbf{I} \frac{7}{8}$ in.; $\mathrm{f}$. black with buff streaks; h. pinkish orange.

c. Goosefoot.

17. “ phyllira; $\mathbf{1} \frac{5}{8}$ in.; f. black with buff streaks; h. pinkish orange.

18. " nais; $\mathrm{I} \frac{1}{2}$ in.; f. black with buff streaks; h. pinkish orange. c. Grass.

19. " quenselii; $\mathrm{I} \frac{1}{4}$ in. : f. black with buff streaks; h. ashy brown. c. Honeysuckle. 20. " virguncula; $1 \frac{1}{2}$ in; $\mathrm{f}$. black with buff streaks ; h. pinkish orange.

c. Polygonum.

2. " arge; $\mathrm{I}_{4}^{3}$ in.; f. buff with black spots; h. pinkish orange.

c. Evening primrose.

22. Pyrrharctia isabella; 2 in; the brown bear caterpillar; buff with dark brown spots.

23. Phragmatobia nubricosa; $1 \frac{1}{4}$ in.; f. smoky brown ; h. grayish brown. c. Goldenrod.

24. Leucartia acrea; 2 in; saltmarsh caterpillar; injurious when in large numbers; $f$. white, black dotted; h. orange and black dots. 

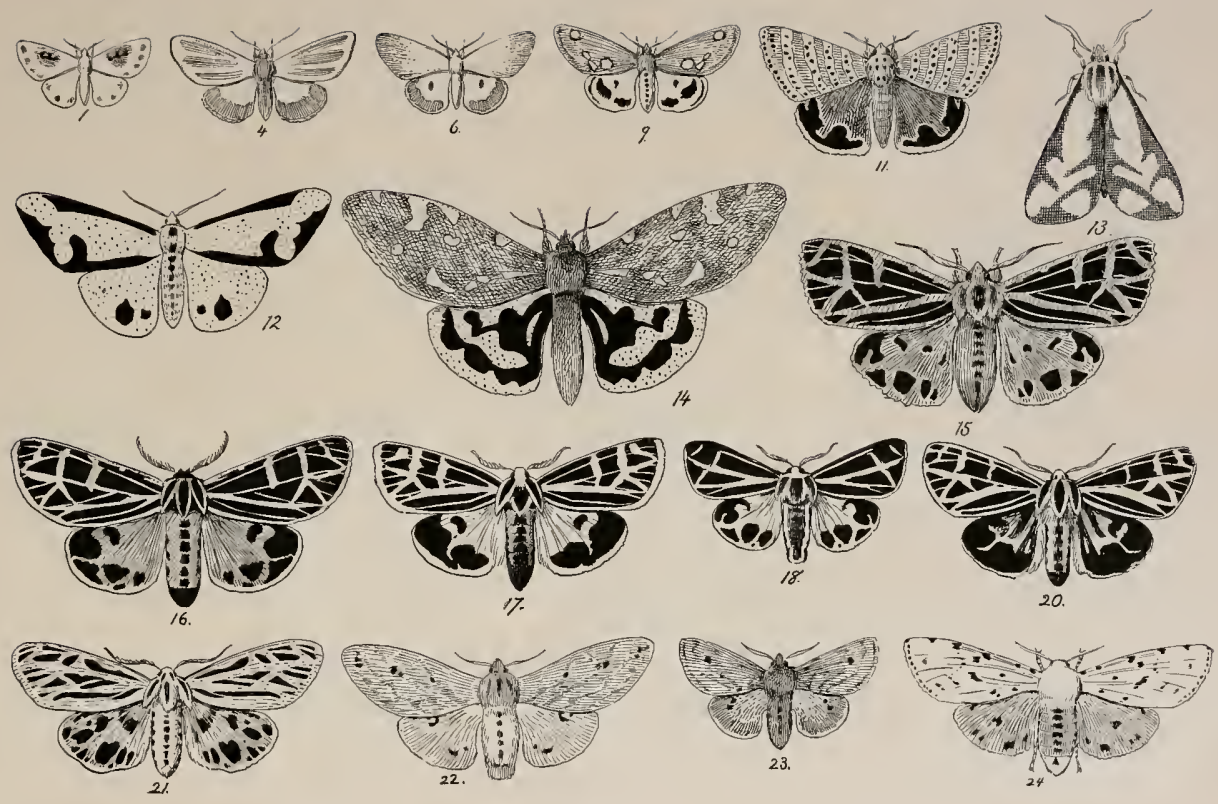


\section{Bombicidæ.}

25. Spilosoma virginica; $1 \frac{3}{4}$ in.; the yellow bear caterpillar; white, two pale dots on hindwing.

26. Hyphantria cunea ; ${ }_{4}^{1}$ in ; f. white with black marks ; hindwing white.

27. " textor; 1 in.; white, not marked.

28. Euchaetes egle; $1 \frac{3}{4}$ in.; semi-transparent buff, body orange; black dotted. c. Milkweed.

29. Halisidota tessellata; $1 \frac{3}{4}$ in.; semi-transparent cream color, body white. c. Maple.

30. " carye; 13 in.; f. buff and transparent white; h. cream color. c. Nut.

31. " maculata; $1 \frac{3}{4}$ in.; f. buff and transparent white; h. white. c. Willow, poplar.

32. Orgyia noz'a; $1 \frac{1}{8}$ in.; f. light brown and black marks; h. rust color. c. Rose.

33. " definita; $\mathrm{I}$ in. ; $\mathrm{f}$. ashy brown and dark brown: h. ashy brown.

34 " leucostigma; $1 \frac{1}{\mathrm{in}}$ in. f. ashy brown and dark brown; h. ashy brown.

c. Maple, apple, pear.

35. Porthetria (Ocneria) dispar; the gypsy moth. Nale I. in.; f. gray, brown and black; h. rust color. Female $2 \frac{1}{4}$ in.; white with black spots and bands.

36. Parorgyia clintonii; $1 \frac{3}{4}$ in.; f. buff gray and brown bands; h. buff

c. Oak. .. parellela; $1_{4}^{3}$ in.; f. buff gray and brown bands; h. buff.

c. Pear, plum.

38. " cinnamomea; I in.; f. buff gray and brown bands; h. buff.
39. Lasoa crispata; 1 in.; light yellow with black and rusty marks.

c. Elm, pear.

40. Euclea querceta; $1 \frac{1}{8}$ in.; rusty buff with greenish white on forewing.

41. Parasa fraterna; $1 \frac{1}{8}$ in.; cream color; rust brown marks on forewing. c. Cherry.

42. Limacoles scapha: $1 \frac{1}{8}$ in.; f. cream and ochre yellow; h. ochre yellow. c. Plum, elm.

43. " biguttata; I in ; f, cream. sandy buff and brown marks; l. cream.

44. “ y-intersa : I in.: f. cream, sandy buff and black marks: h, cream.

45. " fasciola; $\frac{3}{4}$ in. ; f. buff and orange; h. buff.

c. Maple.

46. Fackardia elegans; 3 in.; white, buff and light brown.

47. ". geminata; $\frac{7}{4}$ in.; white, buff and light brown.

48. Isa textula; 3 in.; f. pale buff and pale brown; h. pale buff.

49. Tortricidia testacea; 5 in.; light crean color.

50. Perophora melsheimerii: I $_{4}$ in.; dotted gray with black lines.

c. Oak.

51. Ichthyura inclusa: $\mathbf{1} \frac{\mathbf{1}}{\mathrm{r}}$ in.; f. buff and pale brown ; h. buff.

c. Poplar.

52. " strigosa: $\mathrm{I} \frac{1}{\mathrm{~g}}$ in.; f. buff and pale brown; 1. buff.

53.

“ alhosigma; 1 l in. ; f. buff and reddish brown; h. buff.

c. Poplar.

54 . " vau: I $\frac{1}{x}$ in.; grayish brown and buff, like 53 . 

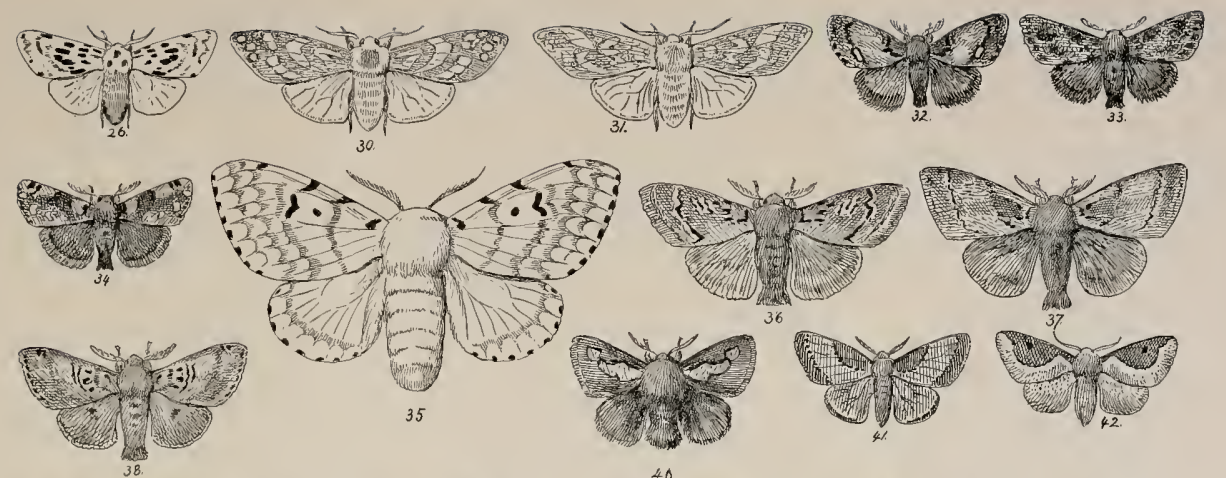

a

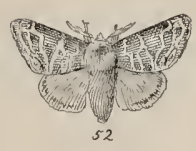

Deve

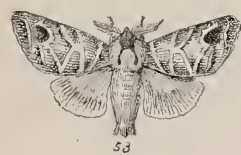

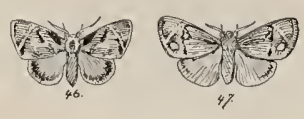

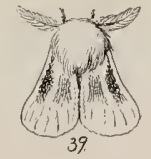

40

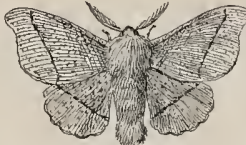
50
(1)

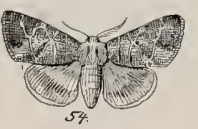




\section{Bombicidæ.}

55. Apatelodes torrefacta : 2 in.; f. light gray and brown; h. rust color.

c. Blackberry.

56. Datana ministra; 2 in.; buff with orange shaded bands on forewing.

c. Nut

57. " contracte : 2 in. ; buff with orange shaded bands on forewing. c. Oak, nut.

58. Nadata gibbosa; 2 in.; buff with orange shaded bands on forewing.

c. Oak.

59. Glubhisia trilinala; $\mathbf{I}_{8}^{1}$ in.; gray buff and dark marks.

c. IVillow.

6o. Notodonta stragula; $\mathbf{1}_{4}^{3}$ in. ; f. buff, gray and brown ; h. cream.

c. Willow.

6r. Lophodonta angulosa; $\mathrm{x}_{\frac{3}{4}}$ in.; f. gray and brown; h. light brown.

c. Oak.

62. Pheosia rimose; $2 \frac{1}{4}$ in. ; f. white, buff and brown; h. white.

c. Willow, poplar.

63. Nerice bidentater: $\mathrm{I}_{\frac{1}{2}}^{1}$ in. ; f. white, buff, gray and brown; h. buff.
64. Edema albifrons; $1 \frac{5}{8}$ in.; gray and dark brown, with silver mark.

c. Oak.

65. Seirodonte bilineata; $1 \frac{1}{2}$ in.; buff, gray and brown ; h. buff.

c. Elm.

66. CEdemasia eximia ; $1 \frac{3}{4}$ in.; like 62 , pale.

67. " badia : $1 \frac{1}{4}$ in.; light buff gray with darker streaks.

68. Dasylophia anguinea; $1 \frac{1}{2}$ in.; light buff gray with darker streaks.

c. Maple.

69. Coclodasys unicomis; $\mathbf{1}_{4}^{1}$ in.; light buff gray with darker streaks. c. Plum, pear.

70. " biguttate : 2 in.; f. gray and brown; $h$. buff and light brown.

71. Heterocampa brunnea; $1 \frac{3}{4}$ in.; f. gray buff and brown; h. white.

" marthesia; $1_{4}^{3}$ in.; f. cream and brown; h. cream.

c. Oak. 

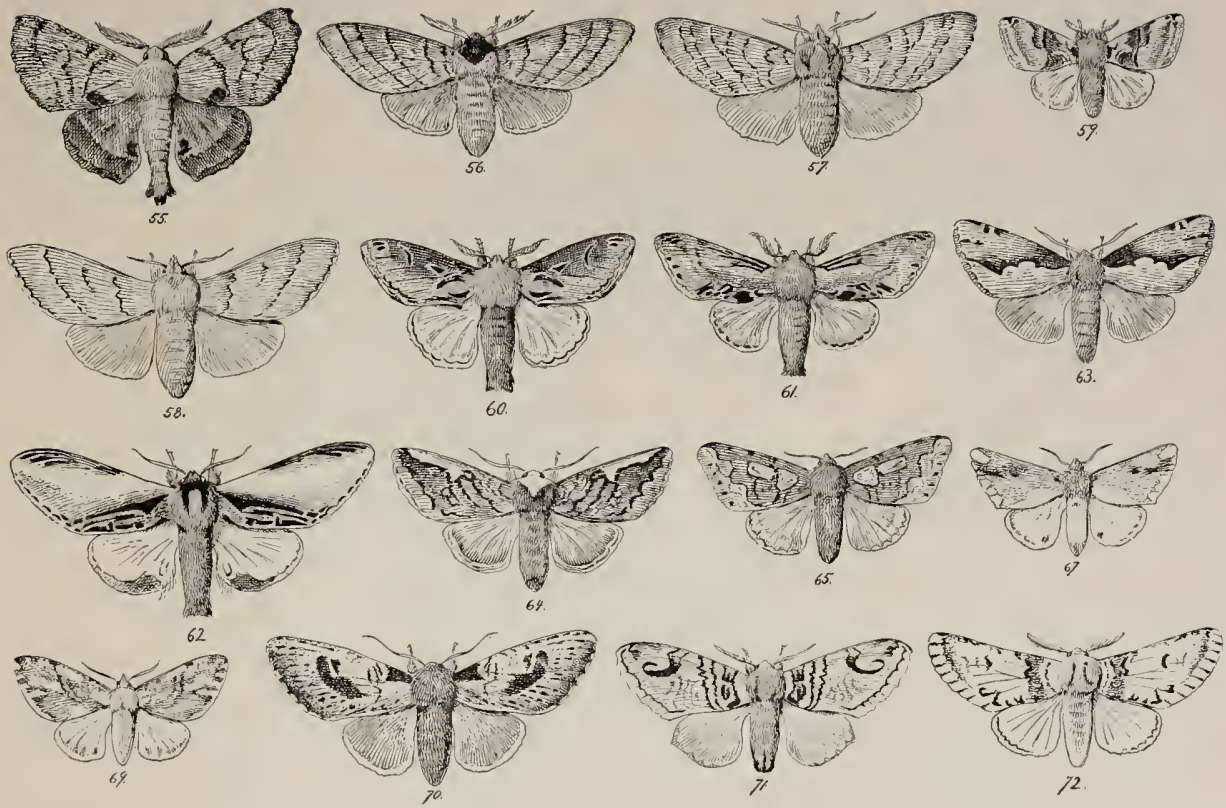


\section{Bombicidæ.}
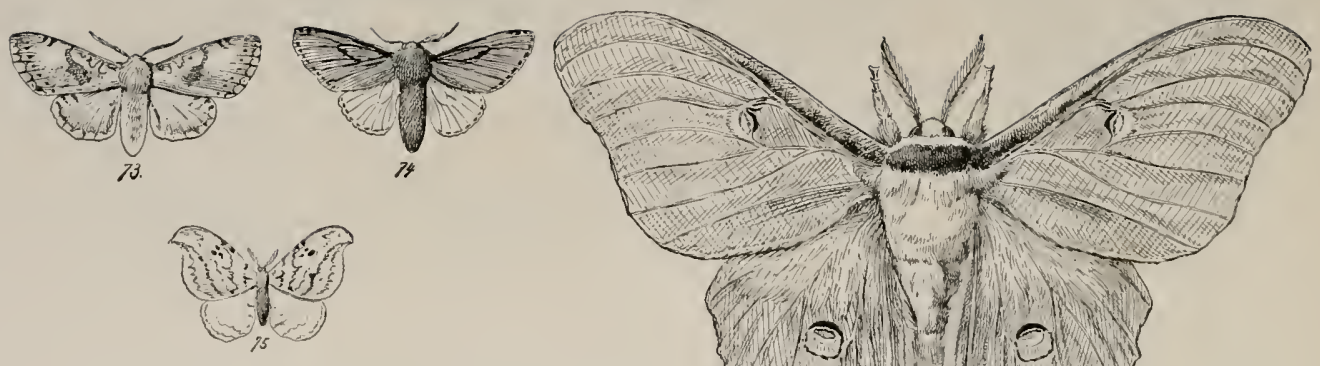

73. Heterocampa biundata; $\mathbf{1} \frac{1}{2}$ in.; white, buff and browil.

74. Cerura borealis; $\mathrm{I}_{2}^{\frac{1}{2}}$ in.; f. transparent gray with black dots; h. light buff. c. Willow.

75. Drepanodes arcuata; $1 \frac{1}{8}$ in.; white and brown.

76. Dryopteris rosea; $1 \frac{1}{8}$ in.; buff and dark brown, like 75 .

77. Ilatypterix bilineata; $\mathbf{1} \frac{1}{8} \mathrm{in.}$; f. cream color with buff lines; h. white.

78. Actias luna; $5 \frac{1}{2}$ in.; pale green, maroon red on front edge of chest and forewing. 


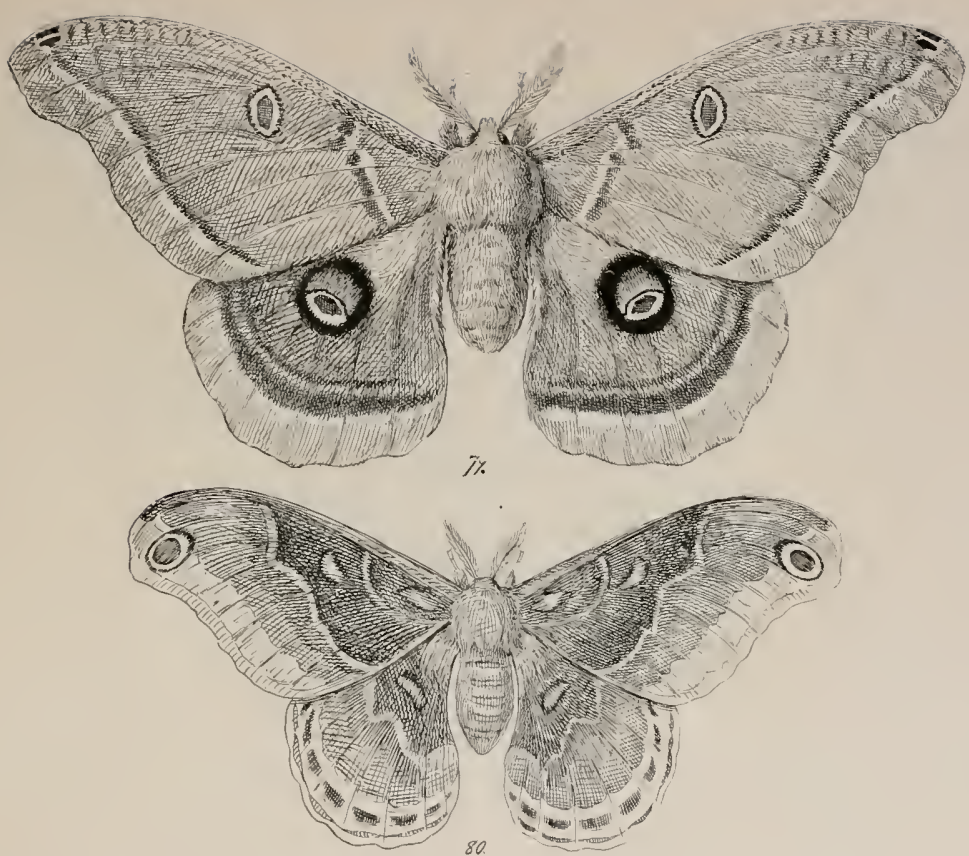

79. Telca polyphemits; $5 \frac{1}{2}$ in.; the American silkworm;
ochre yellow. So. Callosamia prometheat + in.; brown; the male dark
brown. 


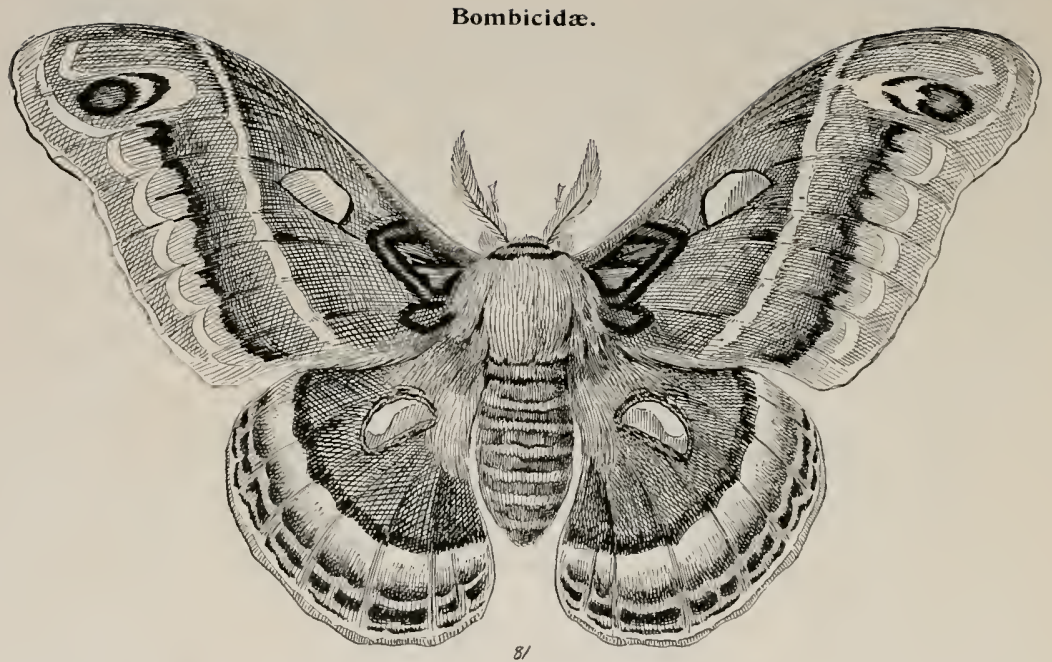

81. Platysamiar cecropict; $54_{4}^{3}$ in. gray, brown and pink; body rust color.

82. Hemiëence mati: $2 \frac{3}{4}$ in.; dark brown with cream colored band on each wing.

83. Hyperchiria varia ; 3 in.; yellow and red.

84. Eacles imperialis: 51 in. ; pale yellow with brown dots. 

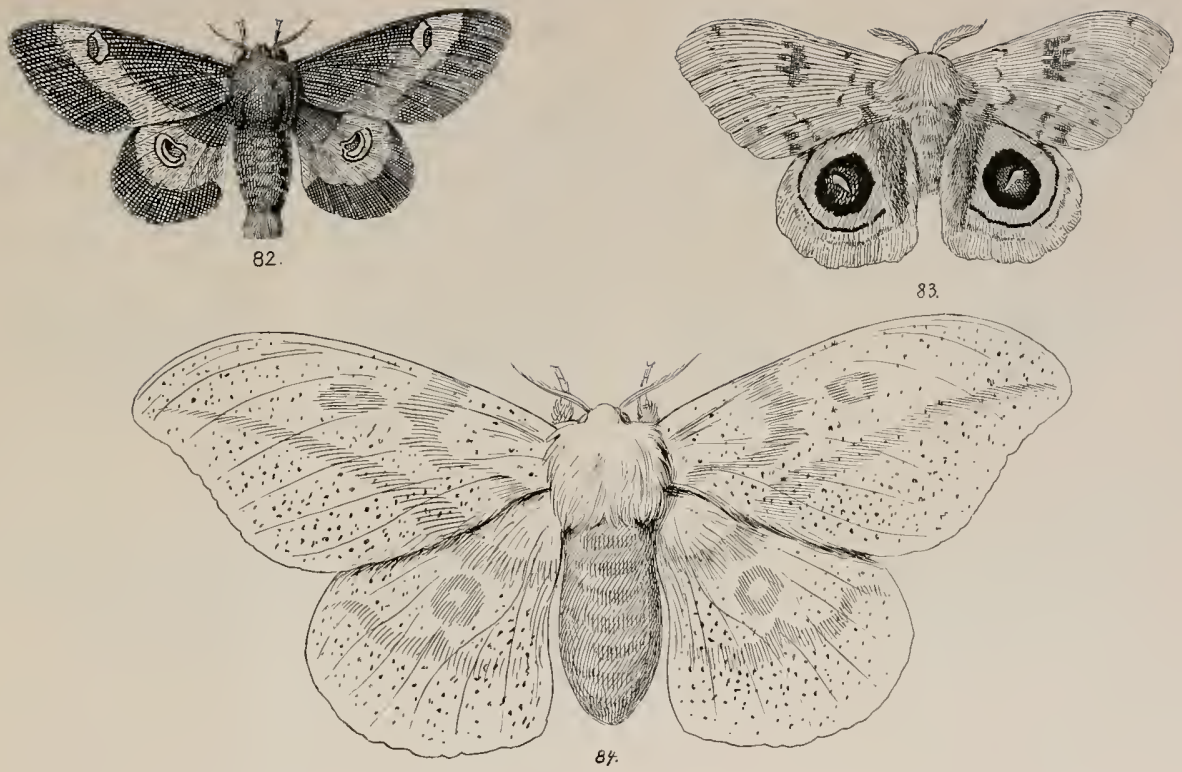

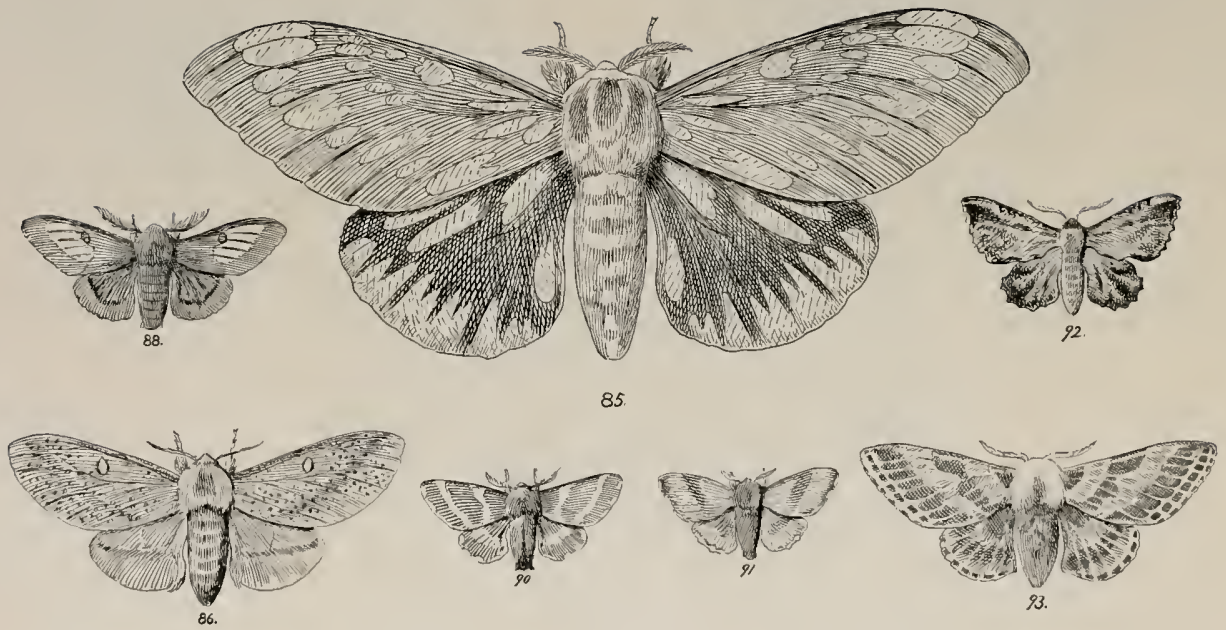


\section{Bombicida}

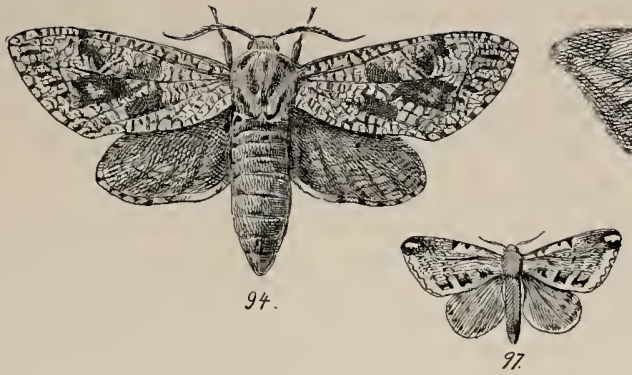

85. Citheronia regralis ; $4_{8}^{3}$ in.; f. olive; h. orange with yellow spots.

86. Anisota stigma; $2 \frac{1}{4}$ in.; buff, one white spot and brown sprinkled. Males, $I_{2}^{\frac{1}{2}}$ in.

87. " senatoria; 2 in.; the oak-forest caterpillar. like 86 ; not sprinkled. Males, $1 \frac{1}{4}$ in.

88. “ pellucida; 2 in.; like 86 ; rusty buff, not sprinkled but band stronger. Male, $1 \frac{1}{4}$ in.

89. Dryocampat rubicundla ; 2 in.; almost white, rosy edge.

90. Clisiocampa americana; $1 \frac{1}{4}$ in.; tent-caterpillar on cherry and apple; reddish buff and white lines. 9r. Clisiocampa disstria ; $1 \frac{1}{8}$ in.; the tent-caterpillar on oak and nut; reddish buff and white lines.

92. Gastropacha americana ; $1 \frac{3}{y}$ in.; gray buff, shaded rusty brown.

93. Tolype velleda; 2 in.; gray and white.

94. Aylcutes robinic ; $2 \frac{3}{4}$ in.; gray and dark brown, transparent.

95. Sthenopis argenteo-maculata $; \frac{3}{1}$ in.; ash gray, with two silver spots.

96. .. argentata; $2 \frac{1}{4}$ in.; ash gray with two silver spots.

97. Hepialus mustelinus ; $1 \frac{3}{8}$ in.; light and dark brown. 


\section{Key to Noctuæ. Owlets.}

OBSERVE the width with outstretched wings, if

Two inches, or more:

forewing and hindwing of same color predominant color of forewing light, hindwing black, or with large black marks . hindwing not black marked predominant color of forewing dark, hindwing black or with black marks hind wing not black marked

One inch, or less :

predominant color of forewing light predominant color of forewing dark

Between one and two inches:

forewing and hindwing similar color and marks forewing, urange or yellow hindwing black or dark brown marked hindwing copper color, or orange

. 113, 114, 115, 136, 137, 138, 140,182, 105, 227,228 . $176,177,181$ to $184,197,198,200$ to 202,219 to 226 . 
predominant color of forewing light, hindwing white or cream color:

forewing light gray

forewing light brown

forewing white, yellow or buff

hindwing gray, or brown :

forewing light gray

forewing light brown

forewing white, yellow or buit predominant color of forewing dark : hindwing white or cream color

forewing gray

forewing brown hindwing gray :

forewing gray

forewing brown
$3,21,45,60,158,16$ I. 92, I I 7, I I 9, I 34, I ́́。. ( I, 2, 4, 5, 9, I 2, 22, 23, 27, 28, 36, $6_{5}, 70,71,90,120$ to $125,133,139$,

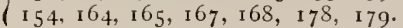

. 8 , I8, I 9, 5 I, 89, I 30 to 132, I 49, I 53, I 59, I62, I63. . $29,30,31,75,77$, I 06 , I 09 , I I 2 . f $10,20,24,25,26,54,9$ I, I 26,127 , ( I 28,144, I 45, I 46, I 55, I 57, I 66 .

( 7, I I, I 5, 34, 44, 46, 52, 57, 58, 66 . $\{76,79$, 102, 147, I 48, I 56, I 88, 19\% - 6, 39, 67, 72, 103, 105, I07, IOS, I I0, 243 .

$\{17,32,33,35,37,47,50,53,55,56,73,78,85,93$, (94, I00, IOI, $116,135,141$ to $143,150,171,174$. $\left\{16,33,40\right.$ to $43,48,49,62,68,69,74,80, S_{1}, 87$, $\{88,95,96,97,99$, I I I, I 5 I, I69, I 70,172, I 73, I 75 . 


\section{NOCTUAE. Owlets.}

r. Leptina doubledayi: $\mathbf{1} \frac{1}{\mathrm{~s}}$ in.; f. cream and brown : h. creamy white.

2. Psculathvatira cymatophoroides; $\mathbf{1}_{4}^{3}$ in.; f. cream and brown; h. cream.

c. Oak.

3. " expultrix; $\mathrm{I} \frac{3}{4} \mathrm{in}$; f. light gray and brown; h. cream and white.

4. Habrosyne scripta; $1 \frac{1}{2}$ in.; f. cream and light brown; h. cream. c. Blackberry.

5. Platycerura furcilla; $1 \frac{3}{4}$ in.; f. cream and dark brown; h. cream.

c. Pine and Linden.

6. Charadra deridens; $1 \frac{1}{2}$ in ; f. cream, light and dark brown: h. cream and white. c. Oak.

7. Rhaphia frater; $\mathrm{I} \frac{3}{8}$ in. ; $\mathrm{f}$. cream, gray and brown; h. white and light brown.

S. Diphtera fallax : 1 in. ; f. white and dark brown; h. light gray brown.

9. Apatela rinula; $1 \frac{1}{8} \mathrm{in.}$ : f. cream, light brown and black: h. cream and light brown.

I o. “. occidentalis; $1 \frac{3}{4}$ in.; f. cream, light brown and black; h. cream and light brown.

c. Cherry.
I 1. Apatela lobelice: $1 \frac{3}{4}$ in.; f. cream, gray and dark brown; h. cream.

c. Oak.

I2. “ populi; $\mathbf{1} \frac{3}{4}$ in. ; white and light brown. 13. .. americana; $2 \frac{1}{2}$ in. ; f. light gray and black; h. buff and light brown.

c. Maple.

I 4. "dactylina; 2 in. ; like 13 ; whitish, pale.

15. " brumosa; $1 \frac{1}{2}$ in. ; f. cream, brown, gray, and black; h. soiled white.

c. Plum and hazel.

16. ". noctizaga; $1 \frac{1}{2}$ in. ; f. cream and dark brown; h. cream and light brown.

c. Poplar.

17. " supcrans; $\mathrm{I} \frac{3}{4}$ in. ; f, cream, brown, gray; and black: h. cream and light brown.

IS. " clarescens; I $^{3}$ in. ; f. light gray, mottled and black; h. cream and gray brown.

c. Plum.

19. " orata; $1 \frac{1}{4}$ in.; f. light gray, mottled and black; h, cream and gray brown. 

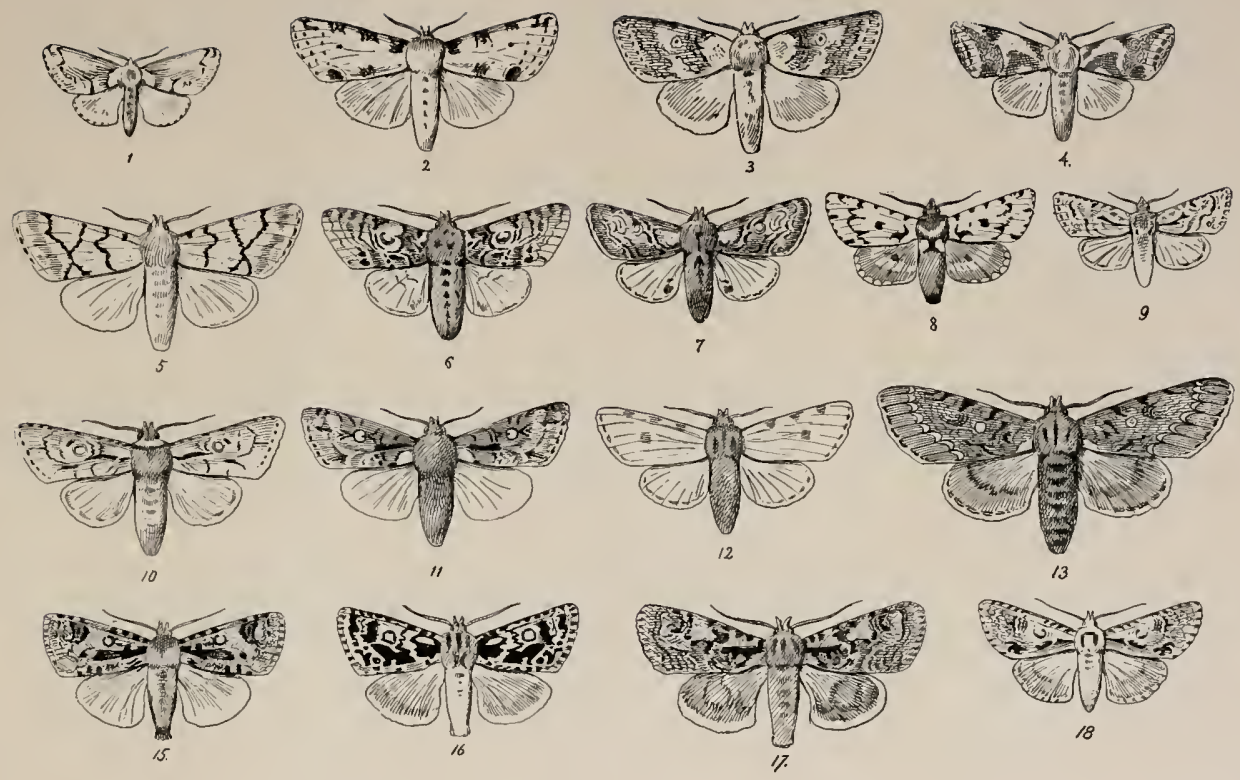


\section{Noctuæ.}

20. Apatela dissecta; $1 \frac{1}{4}$ in.; f. grayish buff and brown ; h. light brown.

21. " sperata; $\mathrm{r} \frac{3}{8} \mathrm{in}$; f. light silky gray and dark gray brown; h. white.

22 " oblinita; $1 \frac{3}{4}$ in.; f. cream and light brown; h. white. c. Peach and asparagus.

23. Arsilonche henrici; $1 \frac{3}{4}$ in. : not marked; f. lirht silky buff with white veins; $h$. white.

24. Harrissimemna trisignata; $1 \frac{1}{2}$ in.; f, cream, bronze colored spots and dark brown; h. cream and light brown.

25. Microcalia obliterata; $1 \frac{1}{4}$ in.; f. white, buff lines and brown; h. cream and light brown.

26. Clytonix palliatricula; $\mathrm{I} \frac{1}{4}$ in.; f. cream, light and dark brown; h. cream and light brown.

27. Igrotis chardinyi; I in.; f. buff and brown; h. white and light brown. c. Grasses.

28. $\quad$ attenta ; 13 in.; f. buff and brown, like 29 ; h. white.

39 " plellophora ; 1 in. : f. buff and brown ; h. strongr buff.

30. ". bajiz; 13 in. ; like 31 , but paler.

31. " normantitur; $1 \frac{1}{2}$ in.: f. gray, buff and black; h. gray buff and brown.
32. Agrotis c-nigrum; $\mathbf{I}_{4}^{3}$ in.; f. cream, dark gray, brown and black; h. cream and light brown.

33. .. bicarnea : $1 \frac{3}{8}$ in.; f. cream, dark gray, brown and black; h. cream and light brown.

34. .. subgotlica; $1 \frac{1}{2}$ in.; like $35 ; \mathrm{f}$. less graj, $\mathrm{h}$. white with brown edge.

35. ". herilis; $\mathbf{I} \frac{1}{2}$ in.; f. cream, gray and black; h. light brown, white edge.

36. " plecta; $1 \frac{1}{4}$ in. ; f. buff and black; h. white.

37. " obeliscoides; $\mathbf{I}$ s in. ; f. cream spots, buff and brown; h. white, brown edge.

3\%. "liaruspica; $\mathrm{I} \frac{3}{4}$ in. ; f. gray; brown and black; h. buff brown.

39. ". fonnica : $1 \frac{3}{4}$ in.; f. gray brown and black ; h. white and light brown.

to " cupida: $1 \frac{1}{2}$ in.; f. reddish brown, buff and black; h. buff and light brown.

11. " altermata; $1 \frac{1}{2}$ in, ; f. like $3^{8}$ in color, but hindwing darker.

42. ". brunniciollis: $1 \frac{3}{m}$ in.; like $3^{S}$ in color.

43. " clantistina; $1{ }^{3}$ in.: like $3^{\mathrm{S}}$ in color.

+4. ." messoria; $1 \frac{3}{4}$ in.; f. light buff, gray and brown; h. white, shaded buft. 
(5) 20.
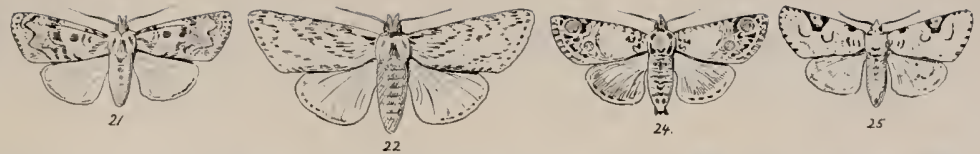

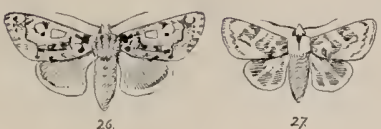
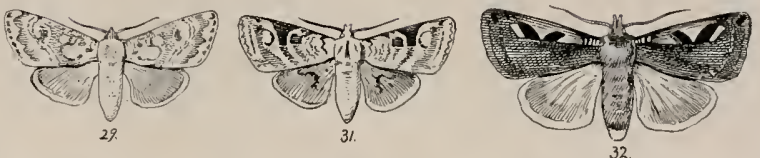

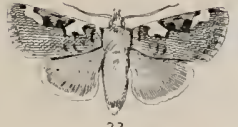

33
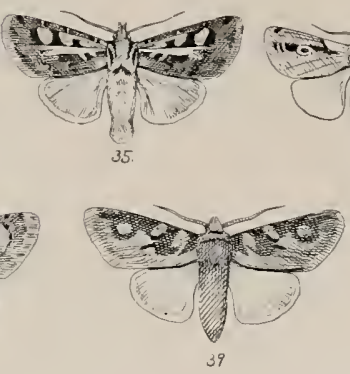

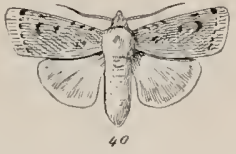

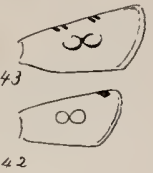

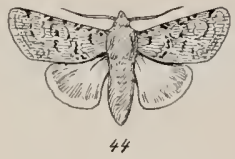




\section{Noctux.}

45. Agrotis murenula; $\mathrm{x}_{\frac{3}{5}}$ in.; f. light buff, gray and faint brown; h. white.

46. " bostoniensis; $\mathbf{1} \frac{1}{2}$ in.; f. buff, gray and dark gray; h. white.

77. " fitychrous; $1 \frac{1}{1}$ in.; f. cream, buff, gray and black; h. cream and light brown.

48. "tessellatu; $x \frac{1}{4}$ in.; f. gray brown and black ; h. cream and light brown.

49. " redimicula; $1 \frac{3}{3}$ in.; f. cream gray, brown and black; h. cream and light brown.

50. " geniculatu; $1 \frac{3}{8}$ in. ; f. light buff gray and brown: h. cream gray and brown.

51. " badinodis: $\mathrm{I} \frac{1}{2}$ in.; f. light buff gray and brown; h. light buff, shaded brown.

52. " relleripennis: $1 \frac{3}{6}$ in. ; f. blackish gray brown and black; h. white and light brown.

53. " fumalis; $1 \frac{1}{2}$ in. ; f. gray brown and black; h. buff and light brown.

54. " monochromatea: $\mathbf{I}_{4}^{\text {l }}$ in. $\mathrm{f}$. buff and light brown ; h. cream with buff bands.

55. " sladiurie; $\mathbf{I} \frac{3}{8}$ in.; f. grayish buff and black; h. grayish cream and light brown.
56. Agrotis venerabilis; $\mathrm{I} \frac{3}{\mathrm{x}} \mathrm{in}$; ; f. light reddish brown and black; h. grayish buff and brown.

57. " rolutilis: $\mathrm{I} \frac{3}{8}$ in. ; f. gray, buff and black: h. white and light brown.

$5^{\text {s. }} \quad$ yston: $\mathrm{I}_{4}^{\frac{3}{4}}$ in.; f. light buff gray, light brown and black; h. white and light brown.

59. " saucia; $\mathbf{1}_{+}^{3}$ in.; ashy gray, like $5^{8}$, but darker.

6o. " lubrians: $1 \frac{1}{2}$ in. : $\mathrm{f}$. light buff, gray and light brown; h. white.

61. " prasina; $2 \frac{1}{4}$ in.; f. cream, light brown and black; h. cream and light brown.

62. Sachnobia carnca; if in.: f. grayish buff, light brown and black; h. cream and light brown.

63. Mamestra furpurissata; 2 in. : f. light grayish buff and brown; h. cream with one light brown band.

64. " nimbosa: 2 in.; f. like $63 ;$ h. with two light brown bands. 

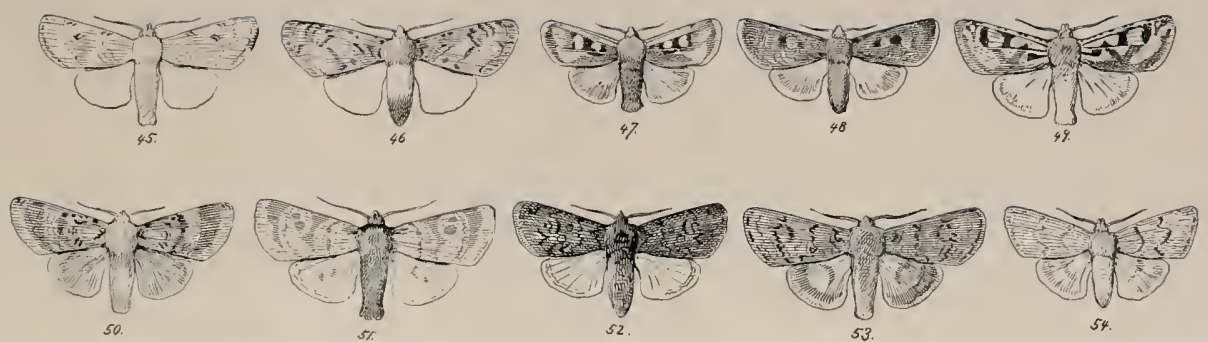

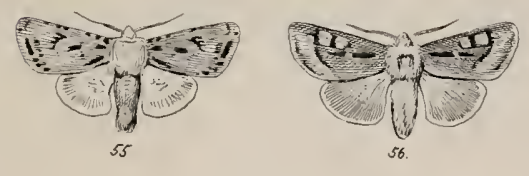
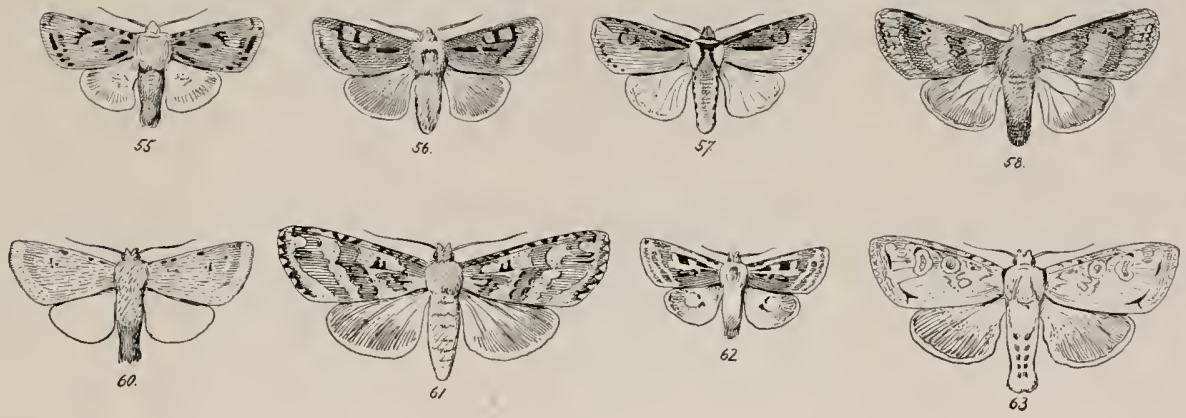


\section{Noctuæ.}

65. Mamestra latex; $1 \frac{1}{2}$ in.; f. cream, gray and black; h. cream and light brown.

66. " adjuncta; $1 \frac{1}{2}$ in.; f. white, gray brown and black; h. white and light brown.

67. "lubens; $1 \frac{3}{4}$ in.; f. cream, brownish gray and brown; h. white and light brown.

68. " legitima; $\mathbf{1} \frac{1}{2}$ in.; f. cream, brownish gray and black; h. cream and buff. 69. " assimilis: 1 s in. ; f. dark gray brown and black; h. buff and light brown.

c. Goldenrod.

70. "6 rosea; $1 \frac{1}{2}$ in.; f. buff and brown; h. cream and light brown.

71. " congermana; $1 \frac{1}{2}$ in.; like 70 , but rear half of body dark brown.

72. $\quad$ picta; 1 i in. ; f, brownish-orange with black outlined white mark; l. white.

73. " granlis: I in. ; f. cream gray and black; h. cream and light brown. c. Bur.

74.
75. Mamestra trifolii; $\mathbf{I}_{2}^{1}$ in. ; f. cream, gray and brown; h. cream and light brown.

c. Goosefoot. 76. " vicina; $1 \frac{1}{8}$ in.; f. cream, gray and clark brown; h. white and light brown.

77. " detracta: 1 in.: f. cream and brown; h. cream and light brown.

78 . " oliz'ace, ; in. ; gray, black and silver white; h. cream and light brown.

79. " renigera; $1 \frac{1}{8}$ in.; like 78 ; h. white with brown edge.

c. Chiccory.

So. " lorea; $1 \frac{1}{4}$ in.; like 78 ; more buff and pale marked.

81. Luceria passer; $\mathbf{1 3} \frac{3}{4}$ in.; f. buff gray and black; h. cream and light brown.

82. Hadina deastatrix; $\mathrm{I}_{\mathrm{J}}^{7}$ in.; f, dark gray with darker marks; h. gray. c. liedstraw.

$8_{3}$. " arctica; 2 in.; f. dark red brown, gray white and black; h. gray.

" dubitans; $\mathbf{I}^{7}$ in.; rusty brown shaded darker, with light mark. 

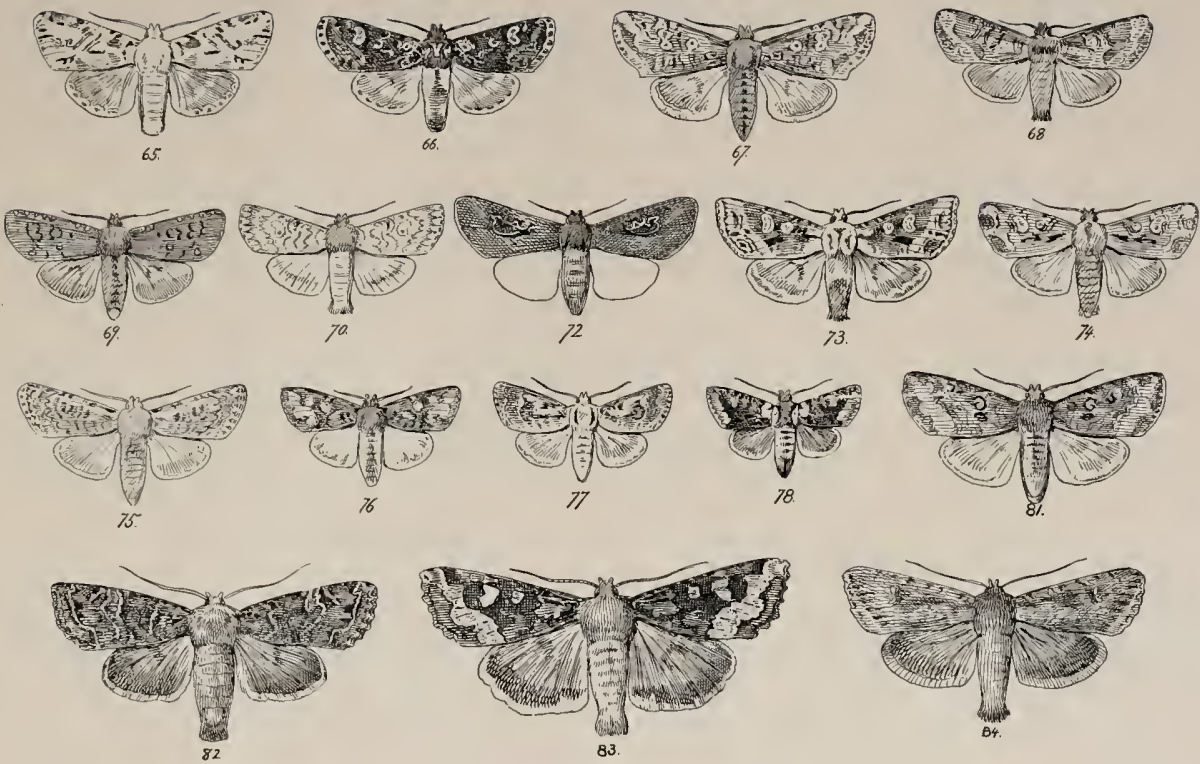


\section{Noctur.}

85. Hadend sputatrix; $\mathbf{1} \frac{3}{4}$ in.; dark brown with indistinct black marks; two bands on hindwing.

86. " lignicolor; 2 in.; buff brown with dark brown marks.

87. " cariosa : $13 \mathrm{in.;} \mathrm{f}$. buff, brown and black; h. cream and light brown.

85. " verbuscoides; $1 \frac{5}{8}$ in.; like $S_{7}$, but paler.

89. . . stipata; $1 \frac{1}{2}$ in.; like 82 , but very pale.

0. " Vritghami; $1 \frac{1}{+}$ in.: f. white, brown and buff marks; h. white.

91. ". Tultuosa; $\mathrm{t}$ in.; like $90 ; \mathrm{f}$. buff and brown ; h. light brown.

22. .. sectilis; $1 \frac{3}{6}$ in.; like $90 ; f$. white and brown; h. white with two light brown bands.

93. " inorilinata; $1 \frac{1}{2}$ in.; grayish cream, light brown and black.

9.4. " finitima; $1 \frac{3}{4}$ in.; like 03 ; much paler :Ind less black marks.

95. ". miselioiles; $1 \frac{8}{8}$ in. ; strong buff, brown and black, with large white mark.

gr. .. molica ; 1 in.; like 95 ; cream and brown. white mark not so large.

97. " fractilinea: 1 l in.; rusty buff, brown and black marked.
98. Oligia chatcedonia; $\frac{7}{8}$ in.; f. cream, light brown and black; h. white and buff.

99. Perigea xanthioides; $\mathrm{I}_{\frac{1}{8}}^{\mathrm{l}}$ in.; buff, light brown and black.

100. Dipterygia scabriuscula; $1 \frac{3}{8}$ in.; dark brown and black, with buff marks. c. Sorrel.

I01. Hypa xylinoides; $15 \frac{5}{3}$ in.; like $8_{7}$; silver gray instead of brown.

102. Ialcric grotci; 1 is in.; f, dark gray, black and white marked; h. transparent white.

103. Actinotin rumosula; $1 \frac{1}{4}$ in.; silvery cream, light reddish-brown and black.

104. Lafliygma frugiperda; $\mathrm{I} \frac{1}{\mathrm{~s}}$ in : like $105 . \quad$ c. Grain.

105. Prodinia ornithogalli; is in.: f, cream, brown and black: h. white with brown veins.

Io6. Trigonophora pericutosa; 1 is in. ; buff and rusty brown.

107. Eplexia lucipara; $1 \frac{1}{\mathrm{~s}} \mathrm{in.;}$ f, brown, cream and black; h. white and light brown.

ro\&. Brotolomie iris; $\mathrm{I}_{4}^{3}$ in; f. buff and light rusty brown ; $h$. white and light brown.

10n. Nephelodes minians: i 7 in.; strong sand color buff and darker marks. c. Grasses.

I o. Ilelotrotha reniformis; $\mathrm{I} \frac{1}{2}$ in.; buff and dark brown.

111. Gortlna sert: $1 \frac{1}{3}$ in.; f. orange and dark brown ; h. lighter with silky shine. 

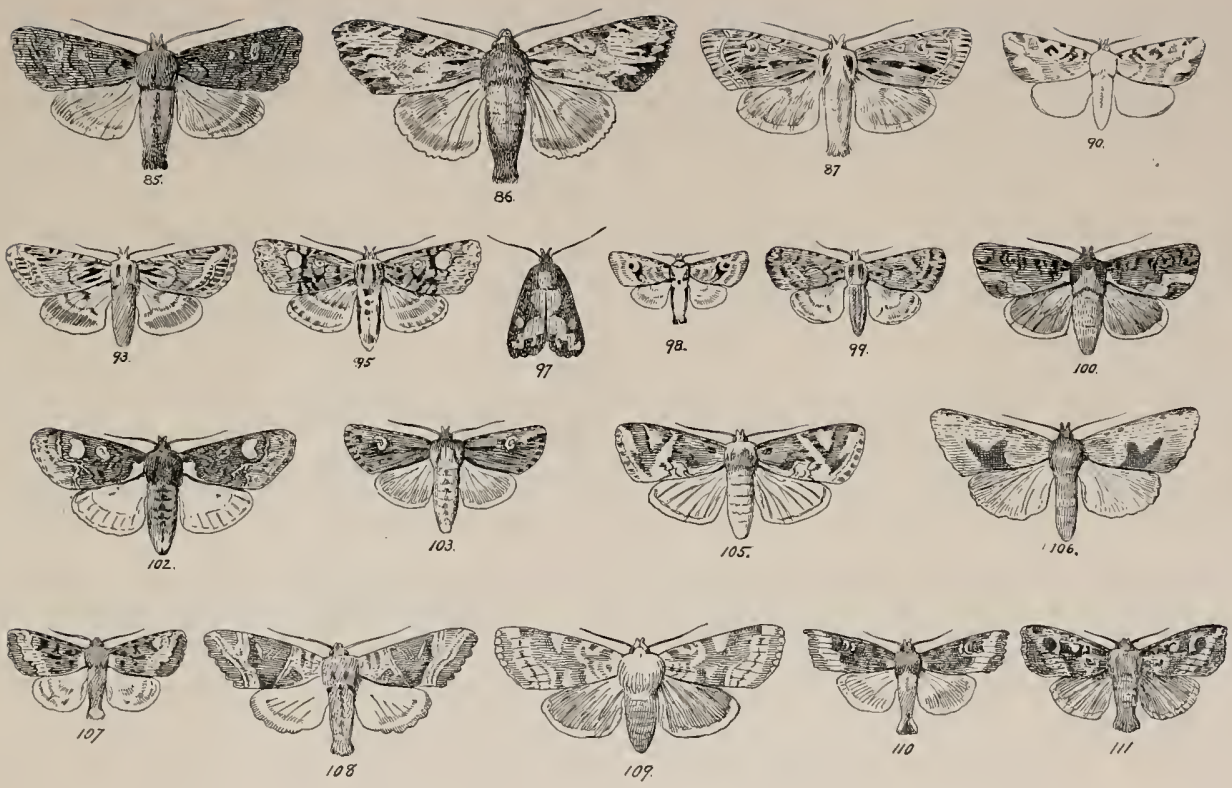


\section{Noctuæ.}

112. Gortyna (Apamar) nictitans; $1 \frac{1}{4}$ in. ; f. orange and light brown; h. lighter with silky shine.

I3. “ . immanis ; $\mathbf{1}_{4}^{3}$ in. ; $\mathrm{f}$. orange; $\mathrm{h}$. cream.

I 4. " rigida; $\mathbf{I}_{4}^{\mathbf{1}}$ in.; f. cream, buff and light brown; $h$. transparent white.

1 15. " limpida; $1 \frac{5}{8}$ in. ; orange and stronger with white marks.

II 6 " " nitclet; $x_{+}^{1}$ in.; light brown.

117. " nebris; $1 \frac{1}{6}$ in.; like I 5 ; but light brown, with white marks.

I 8 . Achatodes zett; $1 \frac{1}{8}$ in.; f. gray, brown and copper color; h. transparent cream.

c. In stems of elder and corn.

119. Nonagria subfar'a; $1 \frac{1}{1}$ in.; buff and brown.

120. Doryodes acutaria ; $1 \frac{1}{2}$ in. ; f. cream and brown; $h$. cream.

12 1 . Platysenta atriciliata; $\mathrm{I} \frac{\mathrm{t}}{\mathrm{s}}$ in.; f. cream and light brown; h. white.

122. Ommatostole lintueri; $\mathbf{1}_{4}^{3}$ in.; f. cream and light brown ; h. white.

123. Heliophila fallens; $1 \frac{3}{8}$ in. ; f. cream; h. white.

c. Grass.

124. " harieyi; $1 \frac{1}{8}$ in.; f. cream and black streaks; h. white and light brown.

125. " phragmitidicola; $1 \frac{1}{4}$ in.; f. cream and brown dots and lines; h. white.
126. Heliophilar commoides; $\mathbf{1} \frac{1}{4}$ in.; f. cream and black lines; h. cream and brown.

127. " unipunctata; $1 \frac{3}{8}$ in.; like $12 S$; second row of dots on $\mathrm{f}$. single; one dot on hindwing.

128. " pseudurgyria; $1 \frac{3}{4}$ in.; cream and light brown; second row of dots on $\mathrm{f}$. double.

129. Pyrophila fyramidoides; $1 \frac{3}{4}$ in. ; f. light and dark brown ; h. copper color.

c. Grapevine.

130.

Graphiphora ovidnea; $1 \frac{1}{8}$ in.; like 131.

" (Taniocampa) incerft ; $1 \frac{1}{2}$ in. ; grayish cream and grayish brown.

c. Oak, willow, plum.

132. Morrisonia zomerina; $1 \frac{1}{1}$ in. ; cream, light brown and black streaks.

133. Orthosid firrngincoides; it in. ; f. crean, faintly marked; h. white.

134. " helza; $1 \frac{3}{5}$ in.; buff and light brown.

135. Gliea sericea; $1_{4}^{3}$ in.; light brown and darker marks.

I36. Jodia rufugo ; $1 \frac{5}{5}$ in.; f. orange and darker ; h. white.

137. Encirratia pampina ; $\mathbf{1}_{6}^{3}$ in. ; orange and brown shaded.

138. Scoliopteryx libatrix; $; \frac{7}{8}$ in. ; light orange, light red spotted, crosslines white. c. II'illow.

139. Santhia togata : $1 \frac{1}{4}$ in. ; cream and pale brown. 


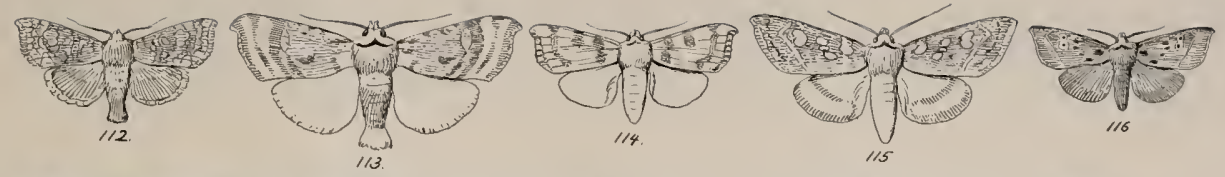

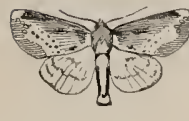

$1 / 8$
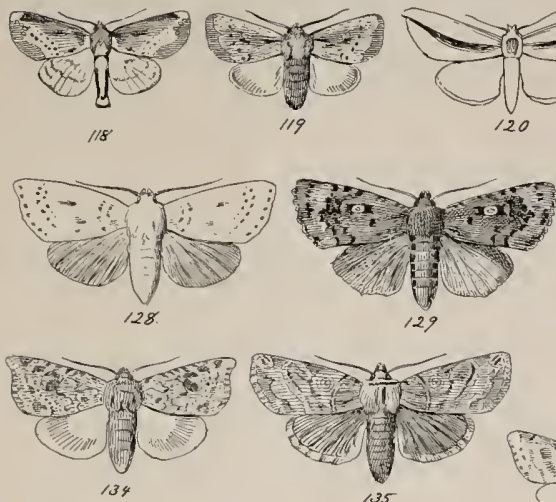

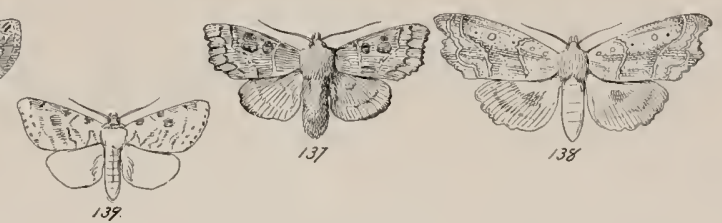




\section{Noctuæ.}

1 40. Scopelosoma pettiti; $1 \frac{1}{4}$ in. ; f. orange ; h. and body white.

IfI. " " morrisoni; $\mathbf{1} \frac{3}{8}$ in.; like 135 ; less marked but spots more distinct.

c. Oak.

142. “ $w^{\prime \prime l l k e r i ; ~} \mathbf{1} \frac{3}{8}$ in.; like 135 ; less marked but spots more distinct.

I 43. " " vimulenta ; $1 \frac{3}{8}$ in. ; like I 35 ; but with white mark above spot in middle of $f$.

14. Lithophane dispositu; I $\frac{3}{5}$ in.; f. whitish gray and black; h. brown. On all fruit trees.

145. " potulia ; 13 in.; like $14+$; larger blurred brown instead of black spots.

146. " bethunei; $1 \frac{1}{4}$ in. ; cream and brown.

147 . " fogina; $1 \frac{3}{4}$ in. : f. slate gray, front edge white; h. light brown.

148. " $\quad$ cincrer ; 1 is in.; dark gray and black with few whitish spots.

149. " builei ; $1 \frac{1}{2}$ in. ; whitish gray and black.

150. " pexatc; I I⿳亠口冋丸 in. ; dark gray, black and white marks.

151. Ithomiu sermatni ; $\mathbf{1}_{4}^{3}$ in.; like 150 ; buff and brown pale.

152. Calocampa nupera ; $2 \frac{1}{4} \mathrm{in}$; light buff gray and dark brown.

153. ". currinacula ; $1 \frac{3}{4}$ in. ; white, light gray and dark brown.

154. Cucullia consexipennis : 13 in.; white, buff and dark brown; h. white and light lorown.

c Goldenrod.
155. Cucullic asteroides; $1 \frac{3}{4}$ in.; white, grayish light brown and black.

156. " intermedia ; $1 \frac{3}{4}$ in.; slate gray and black, white spot near body.

157. Aletia argillacea : $1 \frac{1}{2}$ in.; f. buff and light brown ; h. brown. c. Hollyhocks.

158. Maresmalus zentilator; 1 i in.; transparent white and brown.

I 59. " " histrio; $1 \frac{1}{8}$ in.; transparent white and brown.

I60. Calpe camadensis; $1 \frac{3}{5}$ in. ; buff, brown and black.

c. Meadow rue.

I6I. Telesilla cinerela ; $\mathbf{1}$ in. ; white and gray brown.

c. Ambrosia.

162. Abrostola ozalis ; 1 in. ; like 163 ; paler.

163. " terentis: 1 ! in.; light gray, brown and black lines.

164. I"lusiu efren; $1 \frac{1}{+}$ in.; like $165 ;$ more shaded and no crossline on hindwing.

165. " creoiles; $1 \frac{1}{4}$ in. ; buff and light brown.

c. Spira'a.

"balluca; $1 \frac{1}{2}$ in.; buff, light brown, and silky green gray.

167. " contextu; $1 \frac{1}{4}$ in.; f. cream with light brown lines and white spots; h. white.

c. Grass.

168. " putnumi; 1s in.; like 167; f, crean with light brown band; h. white.

169. “ bimaculatir; 13 in, ; butf, red brown and black with china white spots. 

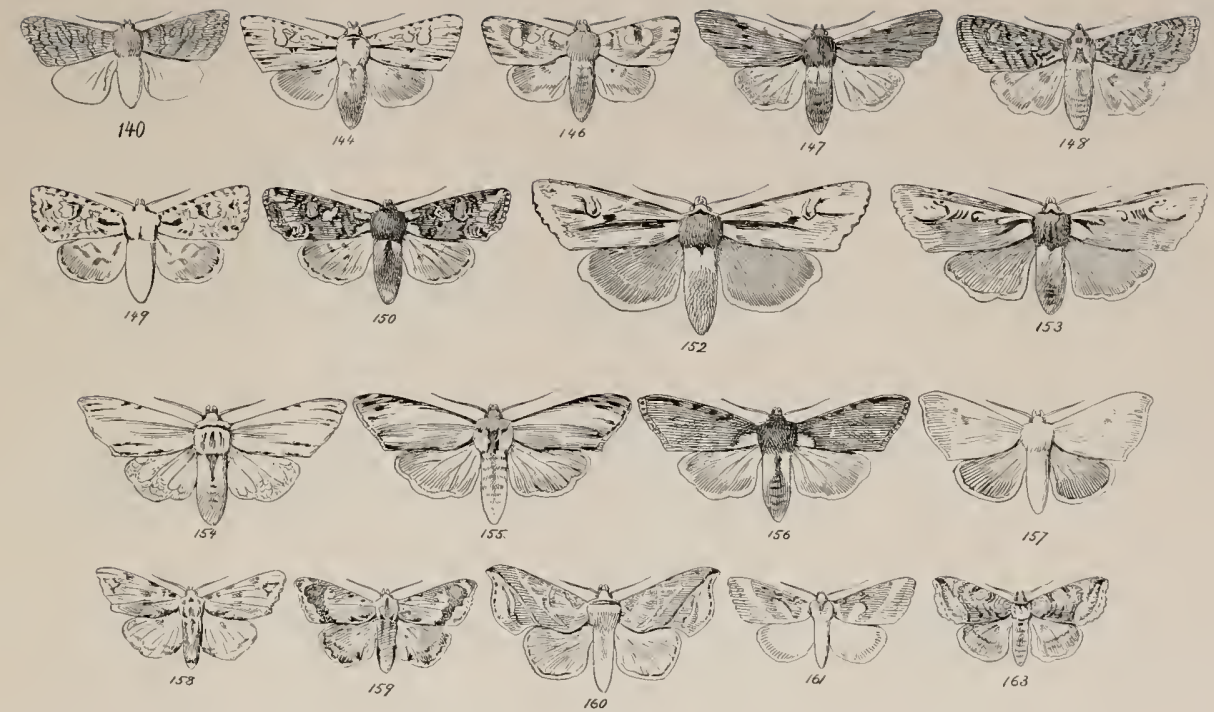


\section{Noctuæ.}

170. Plusia prectionis ; $1 \frac{1}{4}$ in. ; like 169. c. Dandelion.

171. " brassica; $1 \frac{1}{4}$ in.; dark gray, black, silver gray and white marks. c. Cabbage.

172. " mortuorum; 1 l in.; buff brown, white marks larger than $17 \mathbf{I}$.

173. " scripta ; $1 \frac{1}{8}$ in. ; like I7 I ; white marks much larger.

174. " viridisignatu; $1 \frac{3}{8}$ in.; f. light brown with brown spots; h. light brown.

175. .. simplex; $1 \frac{8}{8}$ in.; f. brown and black with silver marks; h. light brown.

176. Anurta melunope; 1 - in.; f. light gray brown; h. black, with edge and mark light.

177. "s schoinher; 1 I in.; like 176 ; f. pale gray; h. pale.

178. Timila mumdina ; 1 in.; f. white with pale brown bands and three black dots, h. white.

179. Rhodofhor florida : Is in.; f. pale cream with indistinct buff marks; h. white.

1So. Iteliothis sfinose: $\mathbf{I}$ in. ; f. cream color and brown : h. white and black.

1S I. Lygranthurcia rivulosa; I I in.; f. gray and black bordered with white lines.

182. "hre is ; $\mathbf{I}$ in.; f. orange rusty, shaded darker; h.l.lack, whiteedge and spots.

183. " spragnei; 1 in.; f. buff and brown: h. white and brown.

18.4. Promite exprimens: 13 in.; f. buff and brown; h. white and light brown.

c. Bush clover.
185. Tartche eretstrioides; $\frac{7}{5}$ in.; f. white, black and gray; h. white with pale brown.

c. Ambrosia. 186. $\quad$ atudifacta ; $\frac{7}{8}$ in. ; like 185 ; but very pale.

187. Lithacolia bellicula ; $\frac{7}{8}$ in. ; silver gray brown, buff spots, white lines and edges.

I8S. Chamyris cerintha : $1 \frac{1}{1}$ in. : f. white, gray and black ; h. white with black dots.

c. Pear trees.

18g. Eustrotia concinnimacnlat ; in.; f. white, black and buff marks; h. white and light brown.

I $90 . \quad$ a synochitis; $\frac{3}{4}$ in.; white, dark brown and buff.

191. " muscosulat; $\frac{7}{8}$ in.; f. gray, black and white ; l. white.

192. " carmeola ; 1 in, ; f. white, black and gray; h. light cream. c. Sorrel.

193. " "friosa ; I in.; f. white, dark gray and black; l. white and light brown.

194. Herrichia mollissima; 1 in.; like 195; but light brown instead of tawny, with large spots and brown lines inside.

195. " monetifier; 1 s in.; f. tawny fox color with stronger shades and pearly white spots; h. cream white.

196. Exyra rolandiana ; $\frac{i}{8}$ in.; f. white and light gray; h. white and light brown.

c. Pitcher plant. 

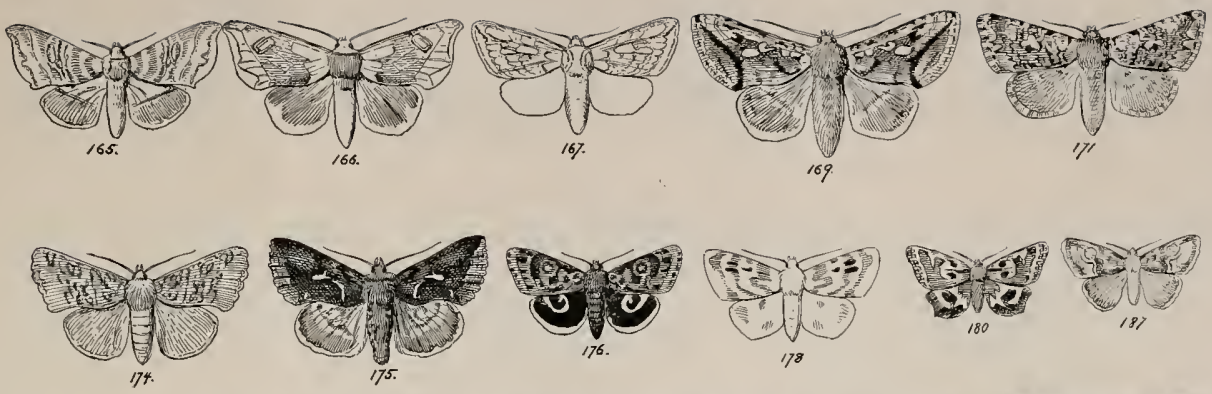

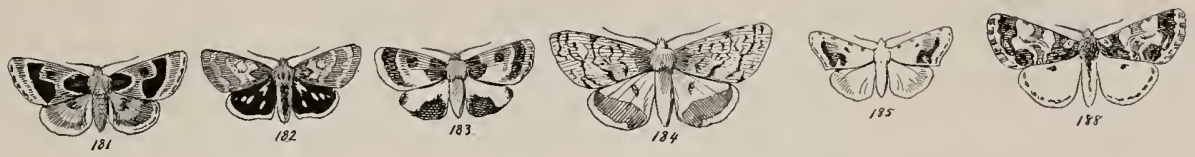
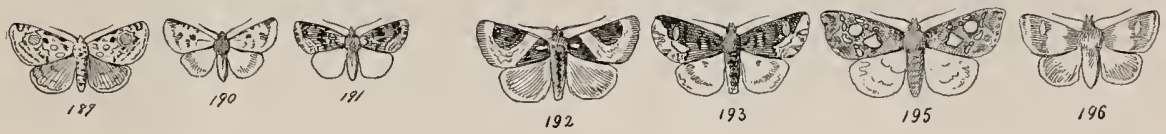


\section{Noctuae.}

197. Brephos infuns : ${ }^{3}$ in. ; f. white, brown and black: h. tawny red and black.

198. Drasteria erechlic ; $1 \frac{1}{2}$ in. ; gray or brown and black.

c. Clover.

199. " crichto; I $\frac{1}{2}$ in. ; like 198 ; but pale brown.

200. Euctidia isspitcet; $1, \frac{1}{2}$ in. ; f. dark gray and black :

l. darker than $19^{8}$.

201. Synede sraphica; $1 \frac{1}{2}$ in. ; f. light gray, black outlined; h. buff and black.

202. Melipotis limbolaris; $\mathbf{1} \frac{1}{2}$ in.; f. gray, white and black; h. buff and black.

203. Parthenos nublitis: $2 \frac{1}{2}$ in.; f. brown with light blotches and black line's; h. orange with 4 black bands. c. Locust.
20.4. Cotocale ifione: $2 \frac{1}{2} \mathrm{in}$; f. dark gray and black; $h$. black with white edge.

c. Oak.

205 . " desperata; 3 in.; f. light gray with few black streaks; h. black with white edge.

c. Nut and oak.

206. " relictı: 3 in.; f. white with black marks ;

h. black with white band and edge.

c. Willow.

207. .. amatrix ; $3 \frac{1}{4}$ in. ; f. dark gray and black ; h. red and black. c. Poplar.

208. " unijugl : $3 \frac{1}{\mathrm{in}}$; ; f. dark gray and black; h. tawny fox color and black.

c. Poplar. 


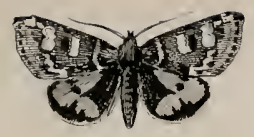

197

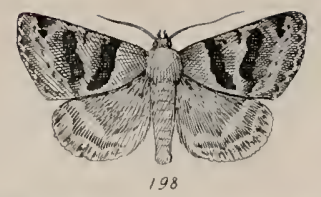

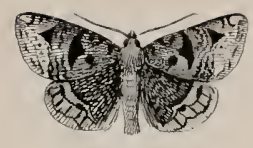

200
(1)

201.
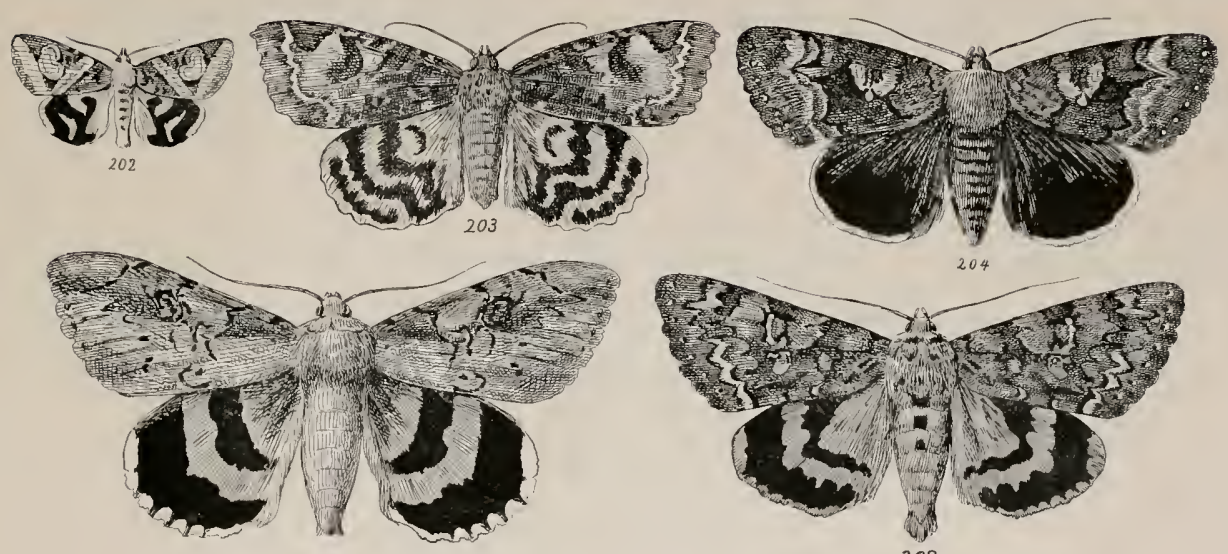

204
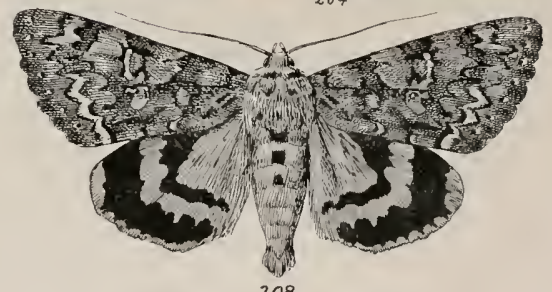


\section{Noctuæ.}

209. Catocala ilic: $3 \frac{1}{4}$ in.; f, dark gray and black; $h$. orange and black.

c. Oak.

210.

" paliegama; $2 \frac{1}{2}$ in.; f. dark gray and black; h. deep red and black.

c. Nut.

211.
"6

concumbens: $2 \frac{3}{4}$ in. ; f. light gray with few black lines; h. pink, red and black bands.

c. Willow.

212. Catocala parta: $3 \frac{1}{2}$ in.: f. light gray, few black streaks and white blotches; h. pink red.

c. IVillow.

213.

" neogama: $3 \frac{1}{t}$ in.; light brown gray with few dark lines and shades; f. like 21 , outer edge of h. like 209 .

c. Oak.

214.

"6 habilis: $2 \frac{1}{4}$ in.: f. light gray with few black marks like 2 I 1 ; h. like 208 , orange and black. 

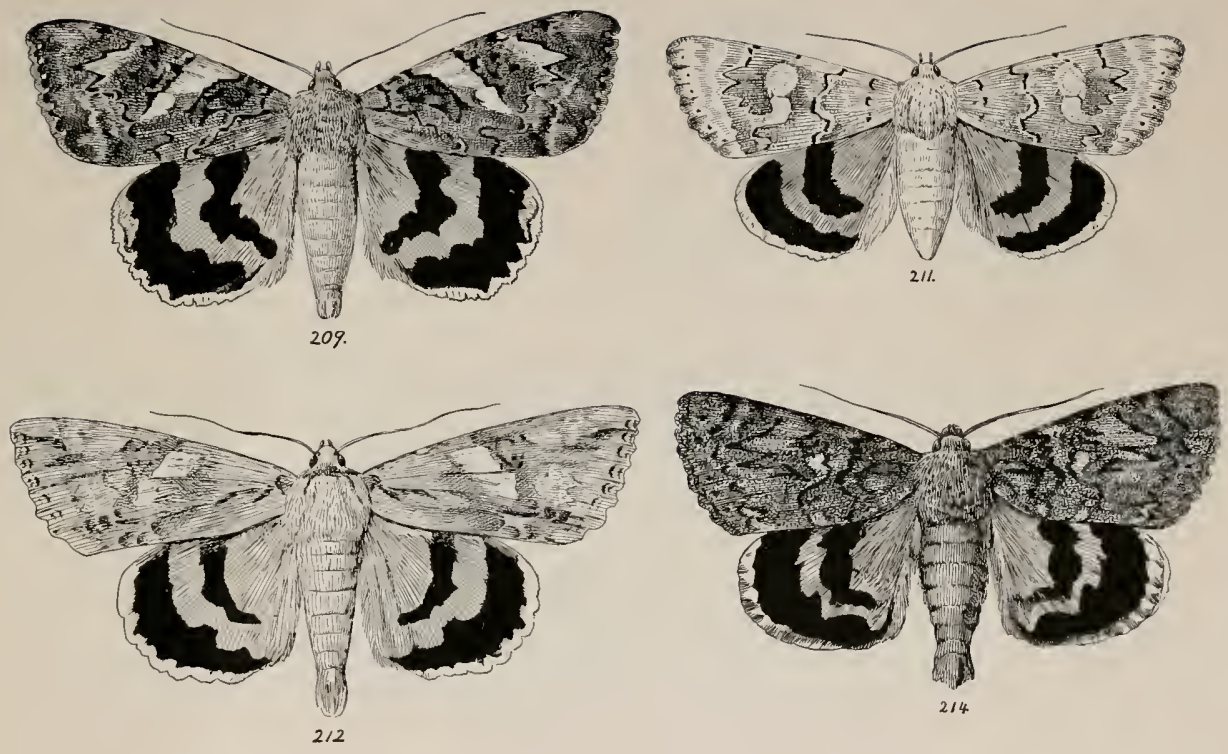


\section{Noctua.}

215 Catocala cara; $3 \frac{1}{2}$ in.; f. dark green, bronze gray, few black streaks; h. bright scarlet and black.

c. Willow.

216. " briseis; $2 \frac{1}{2}$ in.; f. like 204 , brownish; $h$. red and black.

217 . " ultronia : $2 \frac{1}{2}$ in. ; f. light gray, brown and black; h. deep red and black.

c. Plum and oak.

218. " badia; $2 \frac{1}{4}$ in.; light and dark brown bands; sometimes dark blue gray without light marks; h. orange.

219. " polygamu; $1 \frac{3}{4}$ in.; f. gray, buff and black; h. red and black.

c. Hawthorn.

220. " formula; 1 is in.; f. buff, gray, brown and black $\mathrm{h}$, orange and black.

221. " fratercula; $1 \frac{3}{4}$ in. ; f. light buff, gray and black h. orange and black. c. Oak.
222. Cutocala preclara; $\mathbf{1} \frac{3}{4}$ in.; f. gray and black; h. orange and black.

223. " grynea: $\mathrm{I}_{4}^{\frac{3}{4}}$ in.; f. gray, buff and black; h. orange and black.

224. " minuta; $\mathrm{r} \frac{1}{2}$ in.; f. silver gray and dark brown with black marks; h. orange and black.

c. Pear.

225. " amica: $1 \frac{1}{2}$ in.; f. white light gray and black; h. orange and black.

c. Oak.

226. " antinympha: 2 in.; f. dark brown with or without large white spot; h. orange and black.

227. Phoberia atomaris: $1 \frac{1}{2}$ in.; buff and brown with white lines and veins.

228. Pseudo limacudes niveicostatus; $1 \frac{1}{6}$ in.; orange and brown. 

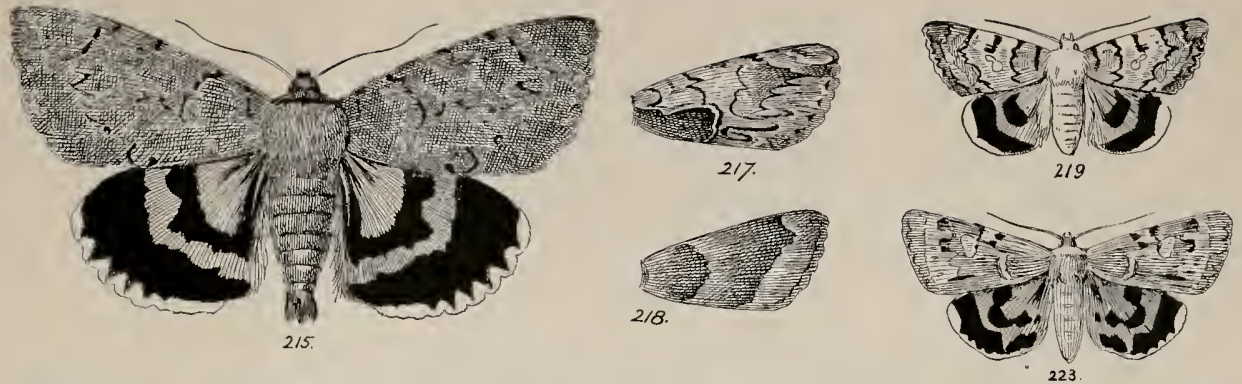

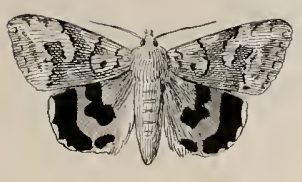

220

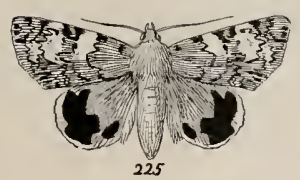

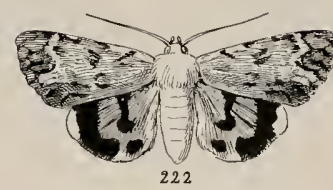

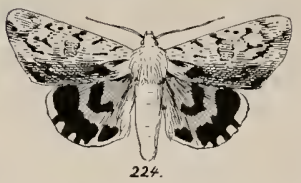

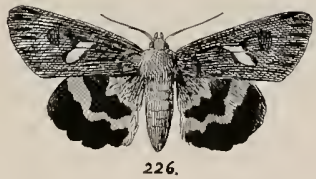

226.

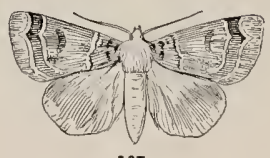

227.

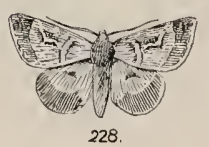




\section{Noctuæ.}

229. Parallelia bistriaris; $1 \frac{3}{8}$ in.; grayish buff with brown and white lines.

c. Red maple.

230. Ianopoda rufimargo; i $\frac{1}{2}$ in.; light buff with brown shaded bands and white lines.

231. Poaphila quadrifilaris; $1 \frac{1}{8}$ in.; dark brown with white edges and bands.

232. Erebus odora: 7 in.; dark brown marked with black lines and eye-spot on forewing.

233. Znle horrida: $1 \frac{1}{2}$ in.; dark brown and cream white with black cross lines.

234. Homoptera cdusa; 2 in. ; cream, buff, brown and black lines. c. Rose and willow. 235. " lumata; 2 in.; buff with brown and black lines.

236. Ypsia undularis: $\mathbf{r}_{4}^{3}$ in.; like 237 ; less distinct and fincr lines.
237. Ypsia cruginosa; $\mathbf{1}_{4}^{3}$ in.; dark brown with black lines and bands. c. Cornel.

238. Pangrapta decoralis; I in.; creamy white with light brown shades and dots.

239. Epizeuxis amul; I in.; very light brown with brown cross band. c. Phlox.

240. " americalis; $\mathrm{I}$ in.; like 239 ; spots on edge dark brown. c. Pea and bean.

24x. Chytolita morbidalis; $\mathrm{I}_{\mathrm{d}}^{\mathrm{l}}$ in.; sandy buff, with faint brown shades.

c. Hazel and grass.

242. Rivula propinqualis; $\frac{3}{4}$ in.; f. silky cream with light brown dot and edge; h. silky white.

243. Bomolocha baltimoralis : $1 \frac{1}{8}$ in. ; cream and brown with black broken lines.

244. Hypana scabra; $1 \frac{1}{2}$ in.; dark gray and brown with black marks. c. Hop and clover. 

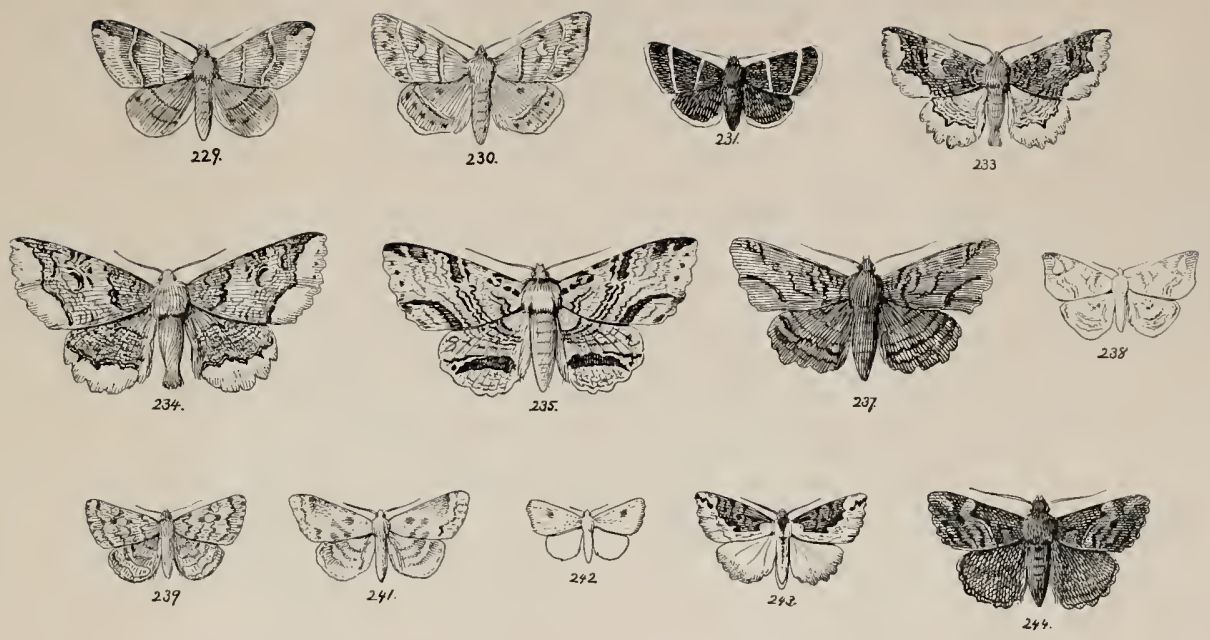


\section{Key to Phalænæ. Geometrids.}

Onserve if

without or with very faint indistinct marks :

color, white

color, buff

marked distinctly:

predominant color buff, yellow, ochre, orange or yellowish brown

predominant color white, cream, gray, or dark brown

color, green . 


\section{PHAL $A N I D A$ (Geometridæ.) Loopers, Spanners.}

1. Eutrapela clematata; $2 \frac{1}{4}$ in. ; buff, brown sprinkled. Caterpillar feeds on elm and clematis.

2. " transiersatı; 2 in. ; cream, buff or brown marked darker. C. feeds on sweet gale and geranium.

3. Tetracis crocallata; $1 \frac{3}{4}$ in.; ochre, yellow and brown. C. feeds on chestnut and sumach.

4. "lorate; $\mathrm{I} \frac{3}{4}$ in ; cream white with faint line from tip to middle across forewing. On sweet fern.

5. Metanema quercizoraria; $1 \frac{1}{2}$ in.; whitish ash, and brown. Caterpillar feeds on oak.

6. ". inatomaria; $1 \frac{8}{8}$ inch; pale gray with pinkish tint. Caterpillar feeds on poplar

7. Drepanodes puber: $\mathbf{1} \frac{1}{4}$ in.; orange buff and light reddish-brown lines.

8. " varus: $1 \frac{1}{4}$ in. ; orange, buff and black speckled, 3 spots on forewing. Feeds on juniper.

9. Caberoles confusaria; $1 \frac{1}{2}$ in.; light gray, outer edge lighter, thickly speckled. Feeds on clover. ro. Caberodes majoraria; $\mathbf{r} \frac{7}{8}$ in.; light yellow.

I I. Eugonia alniaria; $2 \frac{1}{4}$ in.; transparent buff shading to red brown, dark on edge. Feeds on birch, alder, and chestnut.

I2. "subsignaria; $\mathbf{I} \frac{5}{8}$ in.; pure white, shaped like 9 , forewing angled.

Selenia kentaria; $\mathbf{I} \frac{1}{2}$ in.; ochre yellow, violet between lines, like 13 but 3 bands across forewing.

13. Azelina hubnerata; $1 \frac{3}{4}$ in.; reddish brown and dark brown.

14. Endropia serraturia; 2 in.; yellow and fawn.

15. " effectaria; 2 in.; deep fawn speckled with black, deep serrate, extra light line in border.

16. " bilinearia ; $1 \frac{1}{2}$ in. ; brown and dark brown. Feeds on plum and oak.

I 7. " armataria; $1 \frac{1}{4}$ in. ; brown, violet tinge, marks blurred. Feeds on currant.

I8. " textrinaria; $\mathbf{1} \frac{1}{2}$ in.; pale yellow, lines broad and blurred, shape like $\mathbf{9}$. Thickly sprinkled, feeds on oak.

19. " vinulentaria; $\mathrm{I}_{\frac{1}{4}} \mathrm{in}$.; sand color and brown. 


\section{Phalænidæ.}

20. Endropia apiciaria; $1 \frac{3}{8}$ in.; whitish, speckled with light brown.

21 . " hypochraria; $\mathbf{1 5} \frac{5}{8}$ in.; pale brown, with violet tinge.

22. " duaria; $1 \frac{1}{2}$ in.; rust brown, like 19 .

.. maryinata; $1 \frac{2}{4}$ in.; pale ash brown, like 19.

“ amenaria; $1 \frac{7}{8}$ in.; bright yellow, 2 large teeth on apex of hindwing, like 19 .

"s obtusaria; $1 \frac{33}{4}$ in.; pale yellow (sometimes dark brown), border pale.

23. Epirranthis obfirmarit; $1 \frac{1}{2}$ in.; buff or orange sprinkled with brown.

24. Therina fervidaria : $1 \frac{1}{2} \mathrm{in}$, very pale yellow border sometimes.

$a$

" endropiarta; $1 \frac{1}{2}$ in. ; cream.

" seminularia; $1 \frac{1}{2}$ in.; smoky gray or whitish.

25. Metrocampa perlaria; $\mathrm{I}_{4}^{\frac{3}{4}}$ in.; pearly white, crossed by 2 white lines on forewing and $\mathbf{I}$ on hindwing.

Anagoga pulaeraria; $1 \frac{1}{4}$ in.; pale rusty gray with lilac tinge.

26. Sicya macularia; $1 \frac{1}{4}$ in.; bright yellow, buff and brown.

27. Angerona crocatarin; 2 in.; bright yellow with faint brown marks. Feeds on currant and strawberry.

28. Nematocampa filamenturia; $\mathrm{I}$ in.; transparent cream and brown. Feeds on currant and strawberry.
29. Plagodis phlogosaria; I in.; forewing, orange; hindwing, lighter; both brown marked.

“ feridaria; $\mathbf{I}_{4}^{\frac{1}{4}}$ in. : yellow, without dusky streak in border.

“ kreusingaria; $1 \frac{1}{4}$ in.; buff, a dark and light line on hindwing.

" alcoolaria; $1 \frac{7}{8}$ in.; pale yellowish tinge, one line on hindwing.

“ $\quad$ serinaria ; $\mathrm{x} \frac{1}{2}$ in.; bright yellow, only a fraction of a line.

3o. Hyperetis nyssaria; $1 \frac{1}{4}$ in. ; transparent white, brown speckled. Feeds on beach and hypericum.

31. Geometra iridaria ; $1 \frac{1}{4}$ in. ; green with purplish and white line.

32. Aplodes mimosaria; $\frac{1}{2}$ in; green with white lines. Feeds on oak.

33. " rubrifrontalia; $1 \frac{1}{4}$ in.; green, white edge and lines.

34. Synchlora rubizoraria; I in.; green and white. Feeds on blackberry.

Nemoria subcrocentu; I in.; like 35 , bright buff yellow.

“ gratatı; $\frac{7}{3}$ in.; faint lines; dull green.

" pistachata: 1 in.; like 34 ; deep green.

35. Eucrostis chloroleucarin; $\frac{7}{8}$ in; pale green with white lines.

36. Dyspteris abortizaria ; $x \frac{1}{4}$ in. ; greenish gray; white bands; feeds on sunflower. 


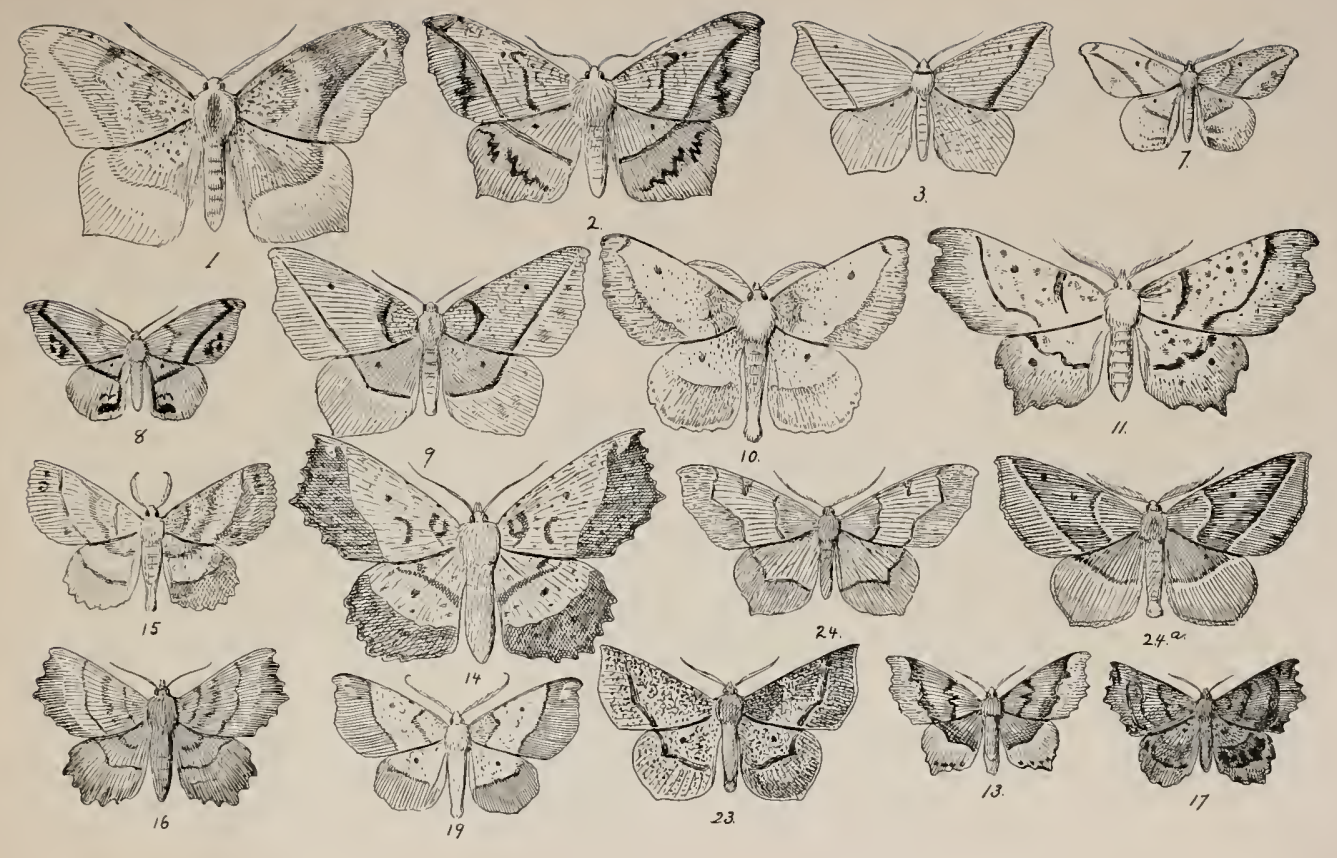




\section{Phalænidæ.}

37. Ephyra pentulinaria; I in.; cream and light brown. Feeds on sweet fern.

$3^{8 .} \quad$ myrtaria ; I in.; transparent white, brown sprinkled. Feeds on sweet fern and huckleberry.

39. Acidaliar insularia: $\frac{3}{4}$ in. ; pale green.

fo. .. nivosata; $1 \frac{1}{4}$ in.; white, with dots on under side of each wing.

4. " inductatu; $\mathrm{I}$ in.; buff and darker marks; $f$. 4 lines, h. 3 lines and dots.

42. “ qualrilineata; $x$ in.; like 41 ; less inner lines, white and buff lines.

43 " on deer grass.

". cacuminate; $\frac{3}{4}$ in.; cream and brown, like 43 .

" rubromarginata; $\frac{3}{4}$ in.; brown, with reddish tinge, like 42 ; lines broader.

.. ossulate; $\frac{3}{4}$ in.; gray; 5 lines in forewing.

44. Asthena albegilzaria; $\frac{3}{4}$ in.; white with 3 buff bands.

.. Incata : I in.; white, brown and ochre.

Eois forrugate; 3 in.; brick red, with 4 brown lines.

45. Stergania fustulariar; I in.; white, speckled with yellow ; indications of bands. Feeds on maple.

Gucneria basiatu; $1 !$ in. : cream, yellow lines, blurred.
46. Deilinia zuriolaria; 1 in.; cream and white.

47. " erythemaria; I in.; cream with yellow speckles and bands.

45. Eudeilinea hermincata; $1 \frac{1}{5}$ in.; white, 2 rows dusky spots on forewing.

49. Corycia vestaliata; 1 in.; white.

" semiclarata; 1 in. ; white and 4 gray bands ; 2 rows of dots on hindwing.

Eumacaria brumnearia; 1 in.; gray with brown marks.

5o. Semiothisa preatomata; $\mathrm{x}_{\frac{3}{5}}$ in.; cream, buff and red brown sprinkled. Feeds on blueberry.

5. " bisignata; $\mathbf{1}_{16}^{3}$ in.; light yellowish gray, speckled brown.

52. .. enotata; $x \frac{1}{4}$ in.; light yellowish.

53. " sranitata; $\mathrm{I} \frac{1}{3}$ in ; granite gray, coarsely speckled.

54. '. ocellinata; I in.; pale gray.

a. multilincata : $x^{1}$ in, ; like 51 , lines stronger, and double, pale gray.

.. minorata; $\frac{7}{5}$ in.; like 50 ; lines stronger, pale gray.

55. Phasiane orillato; $x$ I in.; silver white with brown and black.

56. Marmopteryx strigularia; $1_{2}^{1}$ in. ; dark ash gray.

57. Thamnonoma wotaria; 1 i in.; pale chocolite brown. Caterpillar feeds on currant. I 

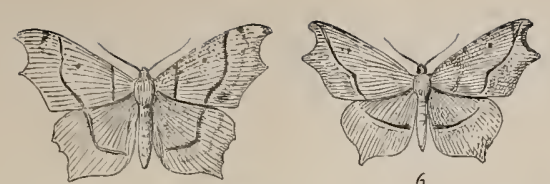

$\frac{(4,2)}{(1)}$

20.

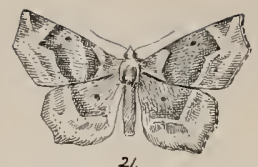

2 (i) $\leq 1$

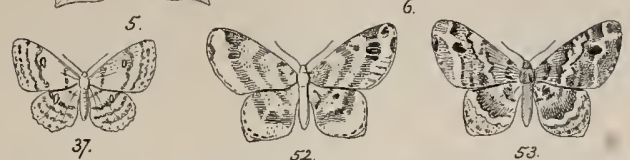

\section{and $=0(5)$} 54.
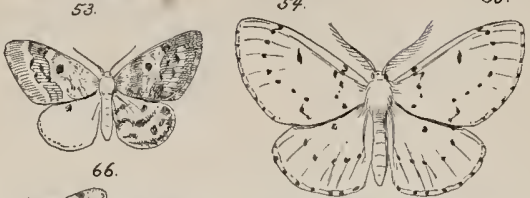
66.

(B) 66

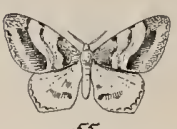

55.

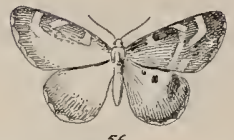

56 62.

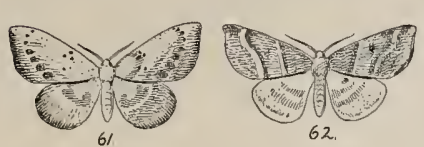

61
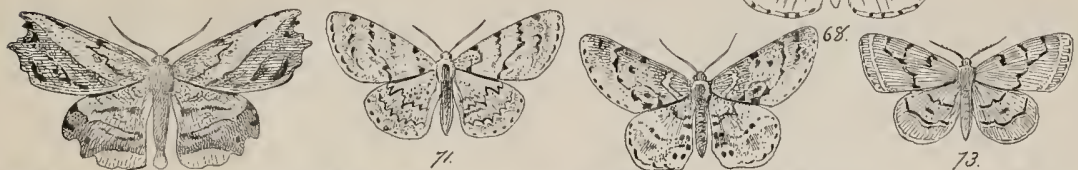

(4). 73 .
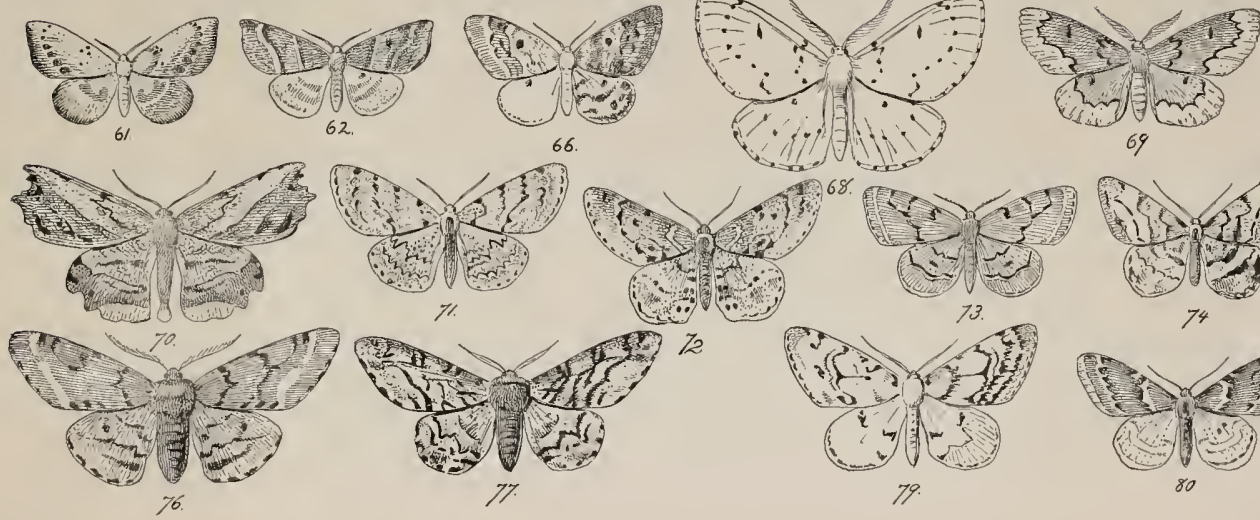

69

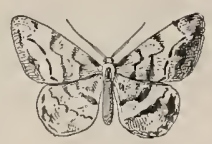

74

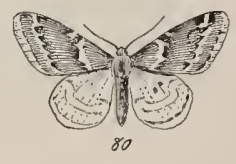




\section{Phalænidæ.}

1) Thamnonomasu/phuraria; 1 in.; jellow with few spots.

" brunnearia : $1 \frac{1}{5}$ in.; brown, like 57. b. 58. " arghlaciaria; $1 ?$ in.; pale brown, no spots.

59. L.osogrammu discomiente; I in.; cream, brown sprinkled.

6o. at detersata; i $\frac{1}{4}$ in.; white, dull yellow sprinkled.

61. " atropunctata: $1 \frac{1}{4}$ in.; buff, gray and black speckles.

62. " tefluata; $1 \frac{1}{t}$ in.; forewing ashy gray with two brown bands; hindwing white.

63. Eufitilia (Alraxis) riberria; $1 \frac{1}{4}$ in. ; light yellow and gray brown. Caterpillar feeds on currant.

6.4. Caripeta angustiorata; I $\frac{1}{2}$ in. ; forewing white and orange; hindwing white. Caterpillar feeds on pines.

" ditisaria; $1 \frac{1}{2}$ in. ; like $64 ;$ white and brown.

65. Ematurga faxonii; $1 \frac{1}{1}$ in. ; cream and red brown.

66. Eufulonia notaturia; I in.; white, brown and gray. Caterpillar feeds on pine.

Fidonia truncaturia; $\frac{7}{8}$ in.; rusty orange, like 65 .

67. Hamatopis staturia; I in. ; orange and red.

68. Zerene catonuria : $1 \frac{1}{2}$ in. ; white with black spots.

69. Cleora fulcharia ; $1 \frac{1}{4}$ in.; white and gray with black lines. Feeds on pines. 7o. Hemerophila unitaria; 2 in.; buff, brown and black.

71. Cymatophora crepuscularia; it in.: white, brown sprinkled. Caterpillar feeds on willow and poplar.

" pampinaria; $\mathrm{r}_{\frac{1}{2}}$ in.: pale ash gray, like $7 \mathrm{I}$.

". humaria ; $1 \frac{1}{2}$ in. ; white dusted brown, border dark.

" lararia; $1 \frac{1}{2}$ in.; whitish gray: 3 spots on tip of forewing.

" nmbresaria ; $1 \frac{1}{2}$ in.; white with black lines.

72. Tephrosia canalaria ; i in. ; gray, brown speckled. " cribrataria; $1 \frac{1}{4}$ in.; like 68 ; ashy buff with strong brown sprinkle and an additional row of dots in border.

" anticaria ; I in.; dull ash gray, like 73 ; but one more line in each wing and separate.

73. " cognaturie; $1 \frac{1}{3}$ in. ; pearly gray.

74. I'araphia subatomaria; $1 \frac{3}{4}$ in.; white, dark brown marked and sprinkled. Caterpillar feeds on pine.

75. " ateplanaria: it in.; like 74 ; buff and light brown. Caterpillar feeds on spruce.

76. Fiston ursaria: $2 \frac{3}{4}$ in. : gray and black with white band in border. leeds on poplar. 

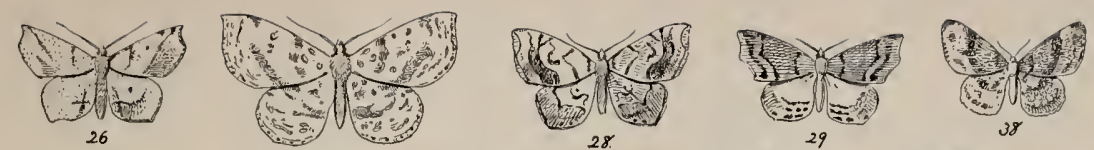

(1)
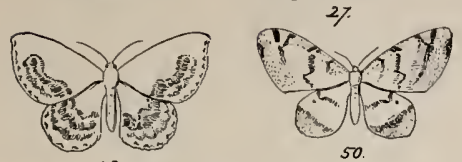

43
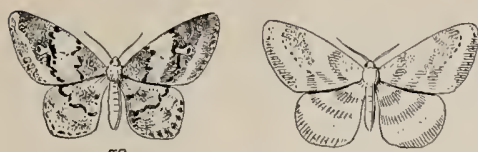

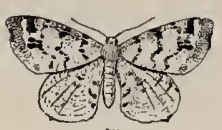

57

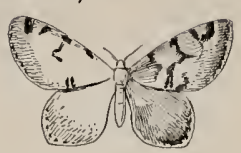

57

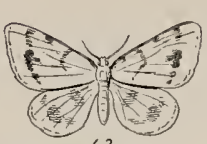

63.

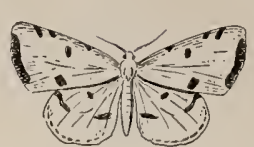

5) ${ }^{8}$
59

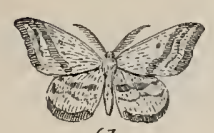

67

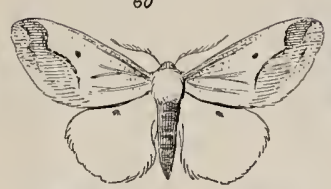

Din

स2:

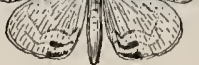

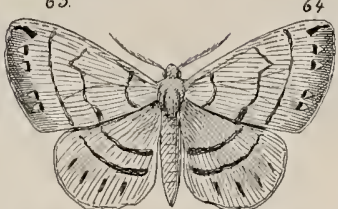

$96^{a}$
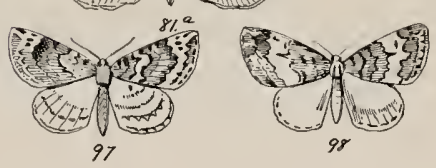

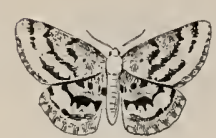

65.

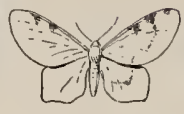

83
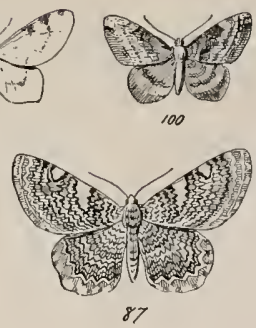


\section{Phalæntidæ.}

77. Amphidasis cognaturia ; $2 \frac{1}{4}$ in. ; brown, black marked and sprinkled. Caterpillar feeds on maple, currant.

Eubyja quernaria; $2 \frac{1}{4} \mathrm{in.}$; white and brown speckled; 2 dark lines in forewing and one in hindwing; like 77 .

78. Hybemia titiaria ; 2 in.; pale yellow with orange speckles; hindwing white.

c. Linden, elm and pear.

79. Phigaliu striguturia ; $\mathbf{1} \frac{1}{2}$ in.; white and dark brown sprinkled on forewing.

c. Rose and elm.

80. Anisopteryx vernata; $1 \frac{3}{8}$ in.; the spring cankerworm; f. gray and brown, h. white.

c. Einı, pear and apple.

8.. " antumnata; $\mathbf{i} \frac{1}{4}$ in.; the fall cankerworm; yellowish gray and brown.

c. Elm, pear and apple.

Aspilates dissimilaria; $1 \frac{1}{2}$ in.; bright yellow and red.

81. 1. " lintneraria : 2 in.; dull reddish yellow.

82. Operophtera boreata; $1 \frac{1}{4}$ in.; white and brown.

83. Ifeterophelps trignttata; i in.; pale yellow and brown. Caterpillar feeds on maple.

84. Odesin allmituta : $\mathrm{I}$ in.; black and white.

85. Carsict paludata; I $_{8}^{1}$ in.; f. gray and brown; h. rusty.

86. Jobophora tcrnata: if in. ; f. white and brown; h. white.
Lobophora anguilincatir: $1 \frac{1}{4}$ in.; greenish white and brown.

" geminata; $1 \frac{1}{4}$ in.; white and black.

Triphosa dubitana; 2 in.; pale reddish gray.

87. Hydria unlulata: $1 \frac{1}{2}$ in.; pale fawn color and black, wavy lines. Caterpillar feeds on plum and willow.

88. Phibalapteryx intestinatu; $1 \frac{3}{6} \mathrm{in}$; d dull gray with 12 black lines.

89. " latirupta ; I in.; white and brown.

Anticlea vasiliatcy; $1 \frac{1}{4}$ in.: dark brown with black bands.

90. Rheumaptira ruficilliata: $1 \frac{1}{4}$ in. ; white, gray and brown.

91. " fluctuati?; I in.; white, gray and brown.

.. intermediati ; $\mathbf{x}$ in.; pinkish gray and black, like $9^{2}$.

92. " lacustrata; $1 \frac{1}{4}$ in. : white and reddish brown.

" unangulata: 1 in. : white with dark gray, like 92.

9.3. .. hicstatc; $1 \frac{3}{8}$ in.; black with white marks.

.. busuliatio; 1 is in.; white and brown like 92.

9+. Ochyria firrugaria; $\frac{\pi}{3}$ in.; white with black and rusty. Caterpillar feeds on Gleehoma. 

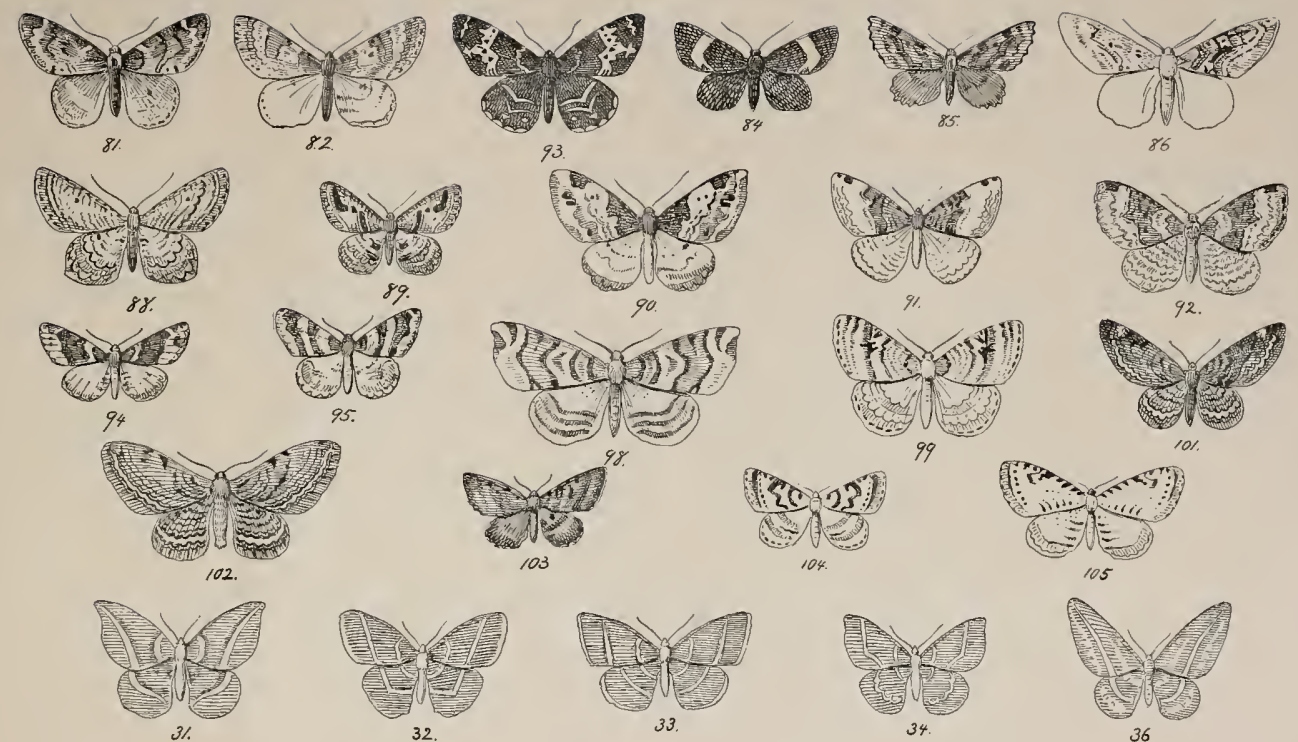

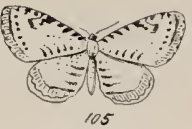

(co.?

$10 \%$

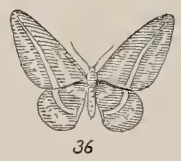




\section{Phalænidx.}

95. Ochyria designata ; $\frac{7}{8}$ in. ; pale yellow. black bands, pinkish tint. Caterpillar feeds on cabbage.

" abrasaria: $1 \frac{1}{6}$ in.; like 95 ; light gray.

96. Petrophora diversilincata; $1 \frac{1}{2}$ in.; orange and brown lines. Caterpillar feeds on grapevine.

96. a. zariety gracilincata.

97. " prunata; $1_{2}^{\frac{1}{2}}$ in. ; f. rusty brown with tan bands, h. white. Feeds on currant.

98. " $\quad$ truncata; $1 \frac{1}{4}$ in. ; white and rust brown bands. Caterpillar feeds on strawberry.

" hersiliata: $1 \frac{1}{4}$ in.; like $9^{\delta}$; blackish gray.

“ cunigeratu; $1 \frac{1}{2}$ in.; like 97 ; pale gray, 4 lines on forewing.

" albolineata : 1 in.; like 97 ; black brown, with white lines.

98. a. .. testata; $1 \frac{1}{4}$ in. ; bright orange yellow. populata; $1 \frac{1}{4}$ in. ; straw yellow, like 93 a.

Ifytriomena trifasciata; $\mathbf{I}_{\frac{1}{4}}^{\frac{1}{4}}$ in.; light greenish gray, like 98 .

Thera contractr; $\mathrm{x}$ in.: pale gray, like 97 .
99. Epirrita cambricaria ; $1 \frac{1}{8}$ in.; white, light and dark brown. Caterpillar feeds on pear.

.. Perlineata; 7 in.; like roo; white with yellowish shade.

roo. Plemyria flutiata: $\frac{7}{8}$ in.; dull clay color and brown. Caterpillar feeds on chrysanthemum.

.. multiferata; $1 \frac{1}{8}$ in.; like roo; reddish brown.

ıо . Glaucopteryx magnotiata: $1 \frac{1}{2}$ in.; f. light gray with dark wavy lines, h. Hesh color.

c. Geranium.

102. "crtaceatu: $\mathrm{I} \frac{3}{8}$ in.; white with gray wavy lines.

103. Eupithecia miserulata; $\frac{7}{8}$ in.; gray with white V on forewing.

104. " albicaptalu: $\frac{3}{4}$ in. ; white with 2 reddish bands.

105. . absynthiate: I in.; pale gray.

". luteata; $\frac{7}{8}$ in. : dark gray, like 103.

.. strattonata; 7 in.; rusty brown, like 103.

“ rarocostaliata: $x$ in.; white and light gray, like 103 or 105. 


\section{PYRALIDÆ, TORTRICIDÆ, TINEID A PTEROPHORIDÆ.}




\section{PYRALID AE. Deltoids, Snout=moths.}

I. Pyralis (Asopia) farinalis; I in.; buff and brown with white border lines.

c. Flour and meal.

2. " costalis; $\frac{7}{8}$ in.; lilac with gold fringes.

c. Clover.

3. Cordylopesa nigrinodes; $\frac{3}{4}$ in.; f. strong buff with white dots; h. white.

4. Scoparia centuriella; $\frac{7}{8}$ in.; gray brown and black.

5. Thelcteria fupula; $\frac{1}{2}$ in.; f. cream color with dark brown dots; h. white.

6. Botis generosa ; $\frac{5}{4}$ in. ; orange and dark brown.

c. Horse mint.

7. " haruspica; $\frac{1}{2}$ in.; f. orange and brown; h.

gray.

8. "plectilis; $\frac{3}{4}$ in.; f. orange and brown; h. white and brown.

9. " tentralis: $\frac{7}{8}$ in.; f. orange buff : h. buff.

10. " octomaculata; $\frac{3}{4}$ in.; black brown with white spots.

I 1. Desmia maculalis; 3 in.; dark brown with white spots.

c. Grapevine.

12. Cindaphia bicoloralis $\frac{5}{8}$ in.; orange and brown.
13. Hydrocampa genuinalis; $\frac{3}{4}$ in.; white and orange with black lines. c. Lives in water.

I 4. Argyia nizalis; $\frac{3}{4}$ in. ; silky white with gold edge.

15. Myelois convolutella; $\frac{7}{8}$ in.; gray with black and white marks. The gooseberry worm.

16. Crambus girandellus; I inch.; satin white, with a broad gold yellow streak in middle of for ewing.

17. ". agitatellus; $\frac{3}{4}$ in. ; f. buff and white, with dark brown lines; h. light buff brown.

18. " laqueatellus; 1 in.; f. white, buff and brown shades: h. light brown with cream colored fringe.

19. " topiarius: $\frac{3}{4}$ in. : f. cream, buff and brown lines; h. light brown with white fringe.

20. Schanobius longirostrella; 1 in.; f. buff with brown line and dot; h. white.

21. Galeria cereana; 1 i in. ; gray and purplish brown. c. Lives in the honeycomb of bees. 

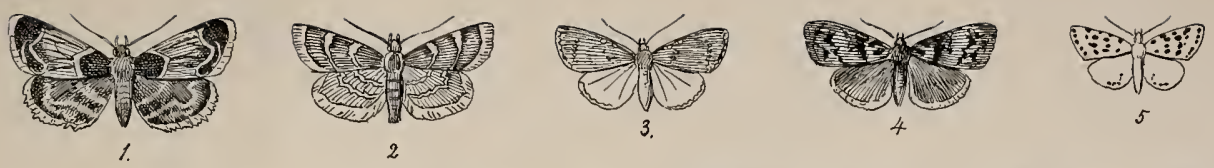
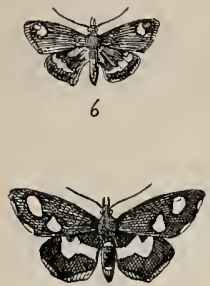

II.

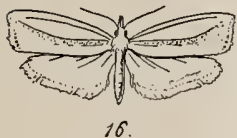

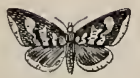

7.

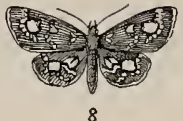

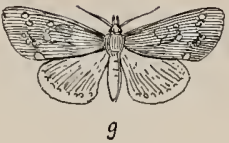

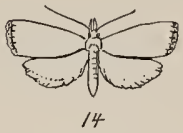

12
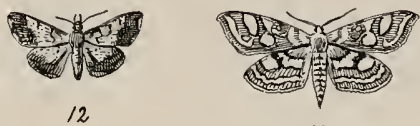

13
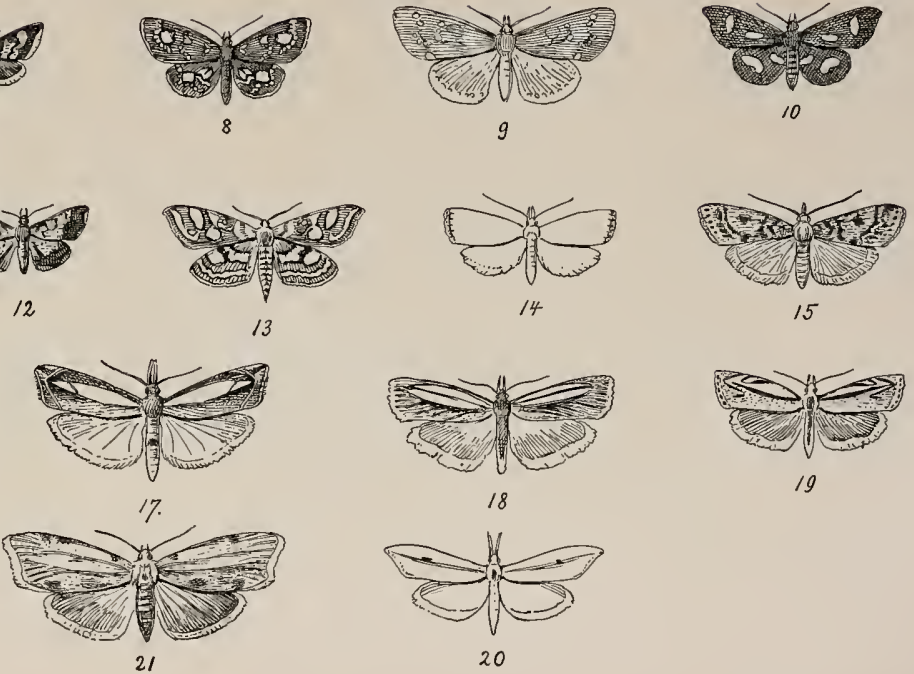
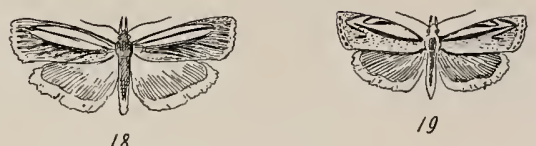

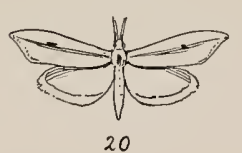




\section{TORTRICID $A$ E. Leaf=rollers.}

I. Antithesia pruniana; $\frac{5}{8}$ in.; gray and dark brown and cream; hindwing light brown. c. Lives on plum.

2. Tortrix sulfuriand; $\frac{1}{2}$ in.; light orange and darker, hindwing light cream.

3. Lozotenia resaceana ; $\frac{7}{3}$ in.; pale brown and dark red brown; hindwing light orange. c. Rose, apple, strawberry. 4. " purpurana; $\frac{7}{4}$ in.; dark brown with black blotches and marks.

5. . cerasizorana; $\frac{7}{x}$ in. ; bright orange with brown marks. c. Lives on cherry.

6. “ fragariana; $\frac{3}{4}$ in.; copper red with white spots on edge.

c. On strawberry.

7. Penthina fullerea: $\frac{1}{2}$ in.; light and dark brown.

8. Grapholitha interstinctana; $\frac{3}{8}$ in.; dark brown with silver-white lines and dots.

9. Ecdytsopha insiticiana; $\frac{7}{5}$ in.; light and dark brown.
10. Padisa alorsisignatana; $\frac{7}{x}$ in.; light brown with reddish brown marks.

I I. " otiosana; $\frac{1}{2}$ in.; brown and black; hindwing light brown.

I2. " packardiana; 1 in. ; gray and brown.

13. Sericoris instrutana; $\frac{1}{2} \mathrm{in.}$; dirty white and dark brown.

4. Carpocapsa fomonella: $\frac{1}{2}$ in. ; the apple worm gray and dark brown; hindwing brown.

c. Lives in apples and pears.

15. Anchylopera spircafoliana : $\frac{1}{2}$ in. ; white, black and reddish stripe.

16. " nubeculana : $\frac{1}{2}$ in.; white and light brown. Caterpillar lives on apple and pear.

17. " vacciniana : $\frac{1}{2}$ in.; white and brown. c. Lives in cranberry. 18. " fragarie; $\frac{1}{2}$ in.; reddish brown spotted with black and white, hindwing gray. c. Feeds on strawberry. 

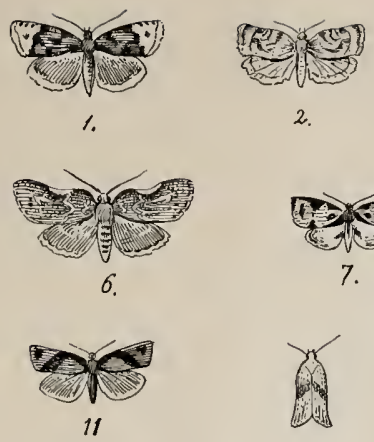
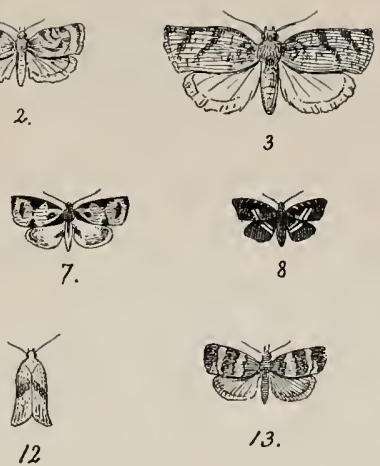
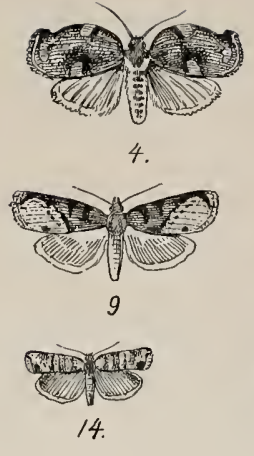
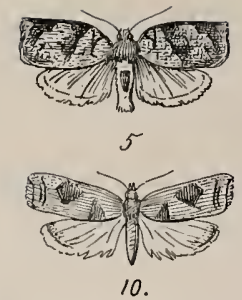
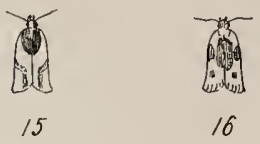


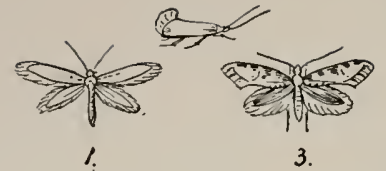

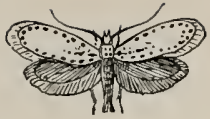

5.

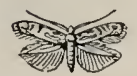

9

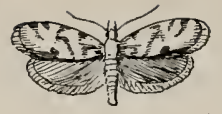

6.

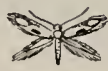

10

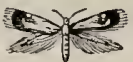

17
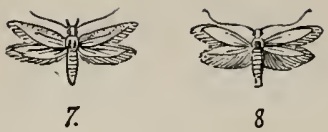

\section{TINEID E. Moths.}

1. Tinet flavifrontella; $\frac{1}{2}$ in.; the common clothes moth; light buff with silky shine; head reddish.

2. '. tapetsella ; the carpet moth ; forewing cream, blackish on shoulder; hindwing dark gray.

3. .. granella; $\frac{1}{2}$ in.; the grain moth; white, brown, and black marbled; hindwing light gray.

4. ." pillioncllir; $\frac{3}{\alpha}$ in. ; the fur moth; yellow silky with a brown spot in the middle of wing.

5. Hyponomeuta millepunctatella; 3 in.; white with dark dots; hindwing gray.
6. Depressaria robiniella : $\frac{3}{4}$ in.: red and brown; hindwing gray.

7. Gelechiu cercalella : $\frac{1}{2}$ in.: light orange with darker spots.

8. Coleophora rosiefoliella; $\frac{1}{2}$ in. ; pale gray and brown ; hindwing darker.

9. Lithocolletis geminatella; $\frac{5}{16}$ in.; gray and black. Grub mines in apple and pear leaves.

10. Bucculatrix pomonella; $\frac{5}{16}$ in.; buff and black. Apple leaf miner.

11. Lyonetia succutella: ${ }^{3}$ in.; gray, orange, white and black. Caterpillar carries a house like a snail. Feeds on apple. 

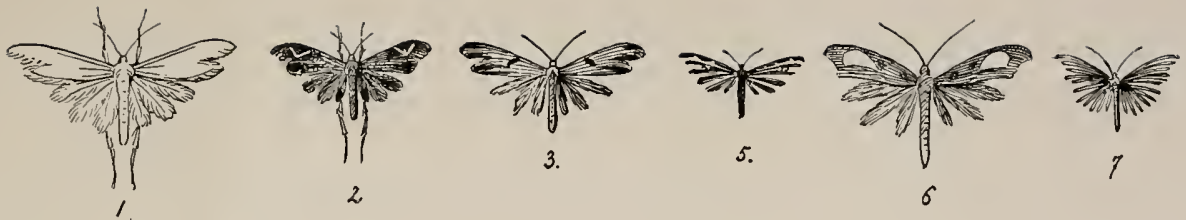

\section{PTEROPHORID $Æ$. Featherwings, Plume=moths.}

1. Pterophoms pentadacty!us; $\frac{7}{8}$ in.: white.

2. " periscelidactylus; $\frac{5}{n}$ in. ; orange, gray and brown,

3. " monolactylus ; $\frac{3}{4}$ in.; buff and brown.

4. Oxyptilus inquinatus; $\frac{1}{2}$ in. ; grayish white.
5. Oxyptilus tenuidactylus ; $\frac{1}{2}$ in.; black.

6. Platyptilus bischoffii; $\frac{7}{x}$ in.; buff and light brown.

7. Alucita polydactyla; $\frac{1}{2}$ in.; each wing of six feathers. Feeds on honeysuckle flowers. 



$$
\text { - }
$$




\section{Knobel's Illustrated Guide Books}

To facilitate the Study of the Natural History of the North.

1. Guide to Trees and Shrubs.

2. The Ferns and Evergreens.

3. Day Butterflies and Duskflyers.

4. Beetles of New England and their Kind.
5. The Night Moths of New England.

6. Fresh-water Fishes of New England.

7. Turtle3, Snakes, Frogs and other Reptiles.

8. Mosquitoes and Flies of the North.

Each Fully Illustrated. Oblong, paper, net 50 cents. Cloth, net 75 cents. Other interesting volumes in preparation.

\section{Some Extra Good Books.}

"Every BIRD." By Reginald Heber Howe, Jr. Fully lllustrated - _ - \$1.00

GAME BIRDS OF NORTH AMERICA. By Frank A. Bates. Illustrated - - 1.00

Sparrows and Finches of New England. By C. J. Maynard. Colored Plates - 1.50

KeY TO THE WATER-BIRDS OF FlORIDA. By Chas. B. Cory. II ustrated - 1.75

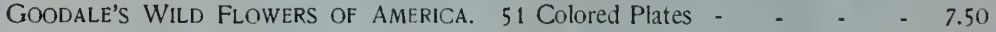

EATON'S Ferns OF NORTh America. 81 Colored Plates. 2 Vo's. - - 4000

BritTon \& BROWN'S ILlustrated Flora OF THE NORTHeRn U. S. 3 Vols. - 9.00

ChapMan's Flora OF THE SOUTHeRn States. New Edition - - - - 4.00

IN PORTIA'S Gardens. By Wm. Sloane Kennedy - $\quad$ - $\quad$ - $\quad$ - 1.50

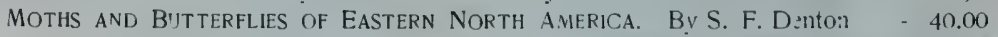

BRADLEE WHIDDEN, PUBLisiger ANo Bookseller, I'Arzh Street, Boston, Mass. 